\title{
Reactive nitrogen in atmospheric emission inventories
}

\author{
S. Reis ${ }^{1}$, R. W. Pinder ${ }^{2}$, M. Zhang ${ }^{3}$, G. Lijie ${ }^{4}$, and M. A. Sutton ${ }^{1}$ \\ ${ }^{1}$ Centre for Ecology \& Hydrology (CEH), Bush Estate, Penicuik, EH26 0QB, UK \\ ${ }^{2}$ US Environmental Protection Agency, Atmospheric Modeling Division, 109 T W Alexander Drive, Research Triangle Park, \\ NC 27711, USA \\ ${ }^{3}$ Institute of Atmospheric Physics, Chinese Academy of Sciences, Beijing, China \\ ${ }^{4}$ The College of Environmental Science and Engineering, Nankai University, Tianjin, 300071, China
}

\begin{abstract}
Excess reactive Nitrogen (Nr) has become one of the most pressing environmental problems leading to air pollution, acidification and eutrophication of ecosystems, biodiversity impacts, leaching of nitrates into groundwater and global warming. This paper investigates how current inventories cover emissions of $\mathrm{Nr}$ to the atmosphere in Europe, the United States of America, and China. The focus is on anthropogenic sources, assessing the state-of-the-art of quantifying emissions of Ammonia $\left(\mathrm{NH}_{3}\right)$, Nitrogen Oxides $\left(\mathrm{NO}_{\mathrm{x}}\right)$ and Nitrous Oxide $\left(\mathrm{N}_{2} \mathrm{O}\right)$, the different purposes for which inventories are compiled, and to which extent current inventories meet the needs of atmospheric dispersion modelling. The paper concludes with a discussion of uncertainties involved and a brief outlook on emerging trends in the three regions investigated is conducted.

Key issues are substantial differences in the overall magnitude, but as well in the relative sectoral contribution of emissions in the inventories that have been assessed. While these can be explained by the use of different methodologies and underlying data (e.g. emission factors or activity rates), they may lead to quite different results when using the emission datasets to model ambient air quality or the deposition with atmospheric dispersion models. Hence, differences and uncertainties in emission inventories are not merely of academic interest, but can have direct policy implications when the development of policy actions is based on these model results.

The level of uncertainty of emission estimates varies greatly between substances, regions and emission source sectors. This has implications for the direction of future research needs and indicates how existing gaps between modelled and measured concentration or deposition rates could be most efficiently addressed.
\end{abstract}

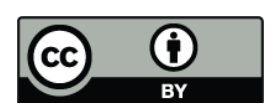

Correspondence to: $\mathrm{S}$. Reis (srei@ceh.ac.uk)
The observed current trends in emissions display decreasing $\mathrm{NO}_{\mathrm{x}}$ emissions and only slight reductions for $\mathrm{NH}_{3}$ in both Europe and the US. However, in China projections indicate a steep increase of both.

\section{Introduction}

\subsection{Aims and objectives}

Nitrogen gas $\left(\mathrm{N}_{2}\right)$ accounts for more than $99.99 \%$ of all the nitrogen present in the atmosphere, while of the rest, again 99\% is accounted for by nitrous oxide $\left(\mathrm{N}_{2} \mathrm{O}\right)$ (Wallace and Hobbes, 2006). Other $\mathrm{N}$ species are thus only present in trace concentrations, but nonetheless play a vital role in atmospheric chemistry. Ammonia $\left(\mathrm{NH}_{3}\right)$ is the most abundant alkaline gas in the atmosphere and is responsible for neutralising acids formed through the oxidation of sulphur dioxide $\left(\mathrm{SO}_{2}\right)$ and nitrogen oxides $\left(\mathrm{NO}_{\mathrm{x}}\right)$, creating ammonium $\left(\mathrm{NH}_{4}^{+}\right)$salts of sulphuric and nitric acid, which become atmospheric aerosols. The only other alkaline gases in the atmosphere are also reduced nitrogen, such as volatile amines, though these are present in much smaller quantities. Oxidized nitrogen, mainly originating as nitric oxide (NO) and nitrogen dioxide $\left(\mathrm{NO}_{2}\right)$ plays a crucial roles both in tropospheric and stratospheric chemistry, for instance in the formation of tropospheric ozone (see Bradshaw et al., 2000; Brasseur et al., 1999).

Nitrogen is thus present in the atmosphere in a multiplicity of chemical forms, contributing both the majority (78\%) of the atmosphere as $\mathrm{N}_{2}$ and a plethora of trace $\mathrm{N}$ components that are fundamental to the atmosphere's chemical and radiative properties. It is convenient to distinguish these $\mathrm{N}$ forms into two main groups: $\mathrm{N}_{2}$ being termed non-reactive (or "fixed") nitrogen, with the sum of all other $\mathrm{N}$ forms present being termed "reactive nitrogen" (Nr) (Galloway et al., 2003, 2008).

Published by Copernicus Publications on behalf of the European Geosciences Union. 
The amounts of $\mathrm{Nr}$ in the world are of fundamental importance to society. Since the invention of the Haber-Bosch process it has become possible to synthesise huge amounts of $\mathrm{NH}_{3}$ directly from $\mathrm{N}_{2}$. The key benefit has been to feed the increasing world population, which is offset by the consequent increases in $\mathrm{Nr}$ losses to the environment (e.g. Erisman et al., 2008). In parallel, high temperature combustion of fossil fuels oxidizes atmospheric $\mathrm{N}_{2}$, causing a huge increase in $\mathrm{NO}_{\mathrm{x}}$ emissions in the atmosphere (Lee et al., 1997). The alteration in agricultural practice and increase in fossil fuel combustion impacts human health, acidification and eutrophication of soils, biodiversity change in terrestrial ecosystems, nitrate eutrophication in freshwater and marine ecosystems and affects the global radiative balance. Furthermore, $\mathrm{N}_{2} \mathrm{O}$ emissions are not only contributing to global warming with a significantly higher global warming potential than $\mathrm{CO}_{2}$ and $\mathrm{CH}_{4}$, but have recently been identified to substantially contribute to stratospheric ozone depletion on a global scale (Ravishankara, 2009). And as $\mathrm{N}_{2} \mathrm{O}$ emissions from agricultural soils are closely linked to $\mathrm{NH}_{3}$ emissions from fertilizer and manure application, it is sensible to address $\mathrm{N}_{2} \mathrm{O}$ emissions in the context of this study, even though $\mathrm{N}_{2} \mathrm{O}$ is typically not classed as reactive nitrogen $\left(\mathrm{N}_{r}\right)$.

While there is sufficient evidence to demonstrate the substantial perturbation of the global nitrogen cycle, the exact quantification of the magnitude and spatial distribution of this perturbation is presently subject to in-depth research. The NitroEurope research project (Sutton et al., 2007; http:// www.nitroeurope.eu) is working towards deriving more precise nitrogen balances from local to regional scales. A major challenge in compiling nitrogen budgets and quantifying pools and fluxes of nitrogen in the atmosphere and biosphere is that models and measurements need to be of good and known quality to allow for a validation of results and ultimately provide the scientific understanding of processes on all relevant spatial scales. The variety of sources of different forms of nitrogen being emitted into the atmosphere, soils and water bodies, their heterogeneous distribution in space and the often high uncertainties regarding specific $\mathrm{N}$ fluxes creates a challenge for the validation and verification of models. At present, closing the gaps in the nitrogen budgets is the aim of major efforts on a global scale. One example for this is the European Nitrogen Assessment Report (compiled under the auspices of the ESF Programme Nitrogen in Europe and the International Nitrogen Initiative), which is due to be completed by early 2011 and which aims to improve the understanding of the European $\mathrm{N}$ cycle and move towards closing the gaps. Emission inventories are a critical source of information in this process. They are most often compiled for compliance monitoring purposes, e.g. EMEP under the UNECE Convention on LRTAP or the United Nations Framework Convention on Climate Change (UNFCCC), using officially submitted data compiled by country experts. Other inventories are compiled by researchers with the main aim to provide a consistent and comprehensive set of input data for modelling purposes (e.g. the EDGAR datasets, IIASA GAINS), often using a bottom-up approach with information on emission factors and activity data that are publicly accessible.

In this paper, we focus on regional scale nitrogen emission inventories for the year 2005, with the aim to assess how different methods and data sources influence the resulting inventory datasets. In a second step, we analyse the main drivers for differences identified, and consider how these may affect the usefulness of datasets for atmospheric modelling. Finally, we briefly discuss emission trends from inventory datasets and scientific literature, considering the implications for our conclusions on the use of emission datasets for modelling purposes.

\subsection{Scope}

Anthropogenic activities have a significant impact on the magnitude of $\mathrm{N}$ cycled and released into the atmosphere (see Table 1), for instance, Galloway et al. (2004) calculated a global rate of annual creation of reactive nitrogen $(\mathrm{Nr})$ of $163 \mathrm{Tg} \mathrm{N} \mathrm{yr}^{-1}$ in the early 1990 s, compared to $125 \mathrm{Tg} \mathrm{N} \mathrm{yr}^{-1}$ around 1860 .

The following Table 2 displays the total $\mathrm{N}$ emissions in $\mathrm{Tg}$ for the three regions on which this paper focuses. It illustrates both the similarities and differences between different inventories and the contribution to the atmospheric domain of global $\mathrm{N}$ emissions, which based on the EDGAR v4 inventory (EDGAR, 2009) amounts to approx. $32 \mathrm{Tg} \mathrm{N}$ in the year 2005 .

At the same time, the scientific understanding of many environmental effects of excess nitrogen in the atmosphere has significantly advanced in recent years. Current research into the critical loads of $\mathrm{N}$ deposition both for acidification and eutrophication (see Hettelingh et al., 2008) has led to the establishment of more stringent critical loads, with dynamic modelling approaches being explored to assess the timescales of ecosystem damage and recovery. In addition, the relevance of $\mathrm{N}_{2} \mathrm{O}$ as a contributor to global warming has been acknowledged and emission control strategies no longer focus solely on $\mathrm{CO}_{2}$, which is reflected e.g. by a more detailed integration of $\mathrm{N}_{2} \mathrm{O}$ sources and measures in the GAINS model (Greenhouse Gas - Air Pollution Interaction an Synergies, http://gains.iiasa.ac.at/) or MITERRA (Velthof et al, 2009).

Given the importance of nitrogen-containing species for air quality and climate change, the question emerges if today's inventories of $\mathrm{NH}_{3}, \mathrm{NO}_{\mathrm{x}}$ and $\mathrm{N}_{2} \mathrm{O}$ reflect the current knowledge on emissions of these trace gases. Furthermore, the parallel but rather separated development of emission inventories under air quality related activities (such as the UNECE Convention on Long Range Transboundary Air Pollution) and under the climate change focus of the Intergovernmental Panel for Climate Change (IPCC) and the United Nations Framework Convention on Climate Change (UNFCCC) 
Table 1. Overview of the main sources and sinks of atmospheric nitrogen-containing species. $\mathrm{N}_{2}$ has been listed for completeness, but is not discussed further, as the paper focuses on reactive $\mathrm{N}$ species only.

\begin{tabular}{lllll}
\hline Sources & $\left(\mathrm{N}_{2}\right)$ & $\mathrm{NH}_{3}$ & $\mathrm{NO}_{\mathrm{x}}$ & $\mathrm{N}_{2} \mathrm{O}$ \\
\hline Biogenic emissions from the terrestrial and marine biosphere & & $\mathrm{X}$ & $\mathrm{X}$ & $\mathrm{X}$ \\
Decomposition of proteins and urea from animals & & $\mathrm{X}$ & & \\
Biomass burning and fossil fuel combustion & $(\mathrm{X})$ & $\mathrm{X}$ & $\mathrm{X}$ & \\
Agricultural mineral Nr fertilisation and denitrification & $(\mathrm{X})$ & $\mathrm{X}$ & $\mathrm{X}$ & $\mathrm{X}$ \\
Lightning & & & $\mathrm{X}$ & \\
Sinks & & $\mathrm{X}$ & $\mathrm{X}$ & \\
Wet deposition (as $\mathrm{NH}_{4}^{+}$and $\left.\mathrm{NO}_{3}^{-}\right)$ & & $\mathrm{X}$ & $\mathrm{X}$ & \\
Dry deposition & $(\mathrm{X})$ & & & \\
Biological nitrogen fixation & $(\mathrm{X})$ & & & $\mathrm{X}$ \\
Industrial nitrogen fixation (mainly Haber-Bosch process) & & & & \\
Chemical breakdown in the stratosphere & &
\end{tabular}

Table 2. Emissions in Tg Nitrogen (Tg N) for the three regions analysed in this paper based on a global inventory (EDGAR v4) and national submissions (to EMEP, IPCC) for the year 2005. In the case of the China, no official national inventory was available; $\mathrm{NH}_{3} \mathrm{emissions}$ as estimated for 2006 by Yan et al. (2003) and other data from the IIASA GAINS China model have been used for the comparison. The last column shows global figures of Tg N emitted based on the EDGAR v4 dataset, as well as the share of emissions of the three regions investigated contributing to global emissions in brackets and italics.

\begin{tabular}{|c|c|c|c|c|c|c|c|}
\hline & \multicolumn{2}{|c|}{ EU25 $5^{\mathrm{a}}$} & \multicolumn{2}{|c|}{ USA } & \multicolumn{2}{|r|}{ China } & \multirow{2}{*}{$\begin{array}{l}\text { Global } \\
\text { EDGAR v4 }\end{array}$} \\
\hline & $E D G A R v 4$ & $E M E P^{1} / I P C C^{2}$ & $E D G A R v 4$ & $U S E P A$ & $E D G A R v 4$ & IIASA ${ }^{3} /$ Yan et al. $2003^{4}$ & \\
\hline $\mathrm{NH}_{3}$ & 4.35 & $3.30^{1}$ & 2.81 & 3.02 & 8.43 & $5.80^{4}$ & $33.4(46.7 \%)$ \\
\hline $\mathrm{NO}_{\mathrm{x}}$ & 3.51 & $3.49^{1}$ & 5.48 & 5.61 & 5.59 & $5.20^{3}$ & $28.1(51.8 \%)$ \\
\hline $\mathrm{N}_{2} \mathrm{O}$ & 0.63 & $0.82^{2}$ & 0.46 & 0.65 & 0.68 & $1.18^{3}$ & $3.9(45.1 \%)$ \\
\hline & 8.48 & 7.61 & 8.75 & 9.28 & 14.69 & 12.18 & $65.4(48.8 \%)$ \\
\hline
\end{tabular}

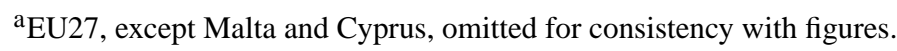

has led to different accounting systems with often differing national budgets for the same trace gas. In this paper, we compare how different approaches to inventory compilation may lead to similar or quite different results and - where possible - discuss likely reasons for differences observed. Specifically, we assess whether the quality of current emission inventories is sufficient to support integrated strategies for $\mathrm{N}$ management, which are emerging in the US and $\mathrm{Eu}-$ rope (Erisman et al., 2007). For this purpose, we here assess existing inventories with regard to their total numbers and sectoral structure. The temporal and spatial resolution, speciation and accessibility of inventories are not the focus of this paper, but will be addressed where necessary.

In the following sections, the current situation of emission inventories in Europe, the US and China is discussed with the focus on how emissions of $\mathrm{NH}_{3}, \mathrm{NO}_{\mathrm{x}}$ and $\mathrm{N}_{2} \mathrm{O}$ are estimated and allocated to source sectors. Aspects of spatial and temporal resolution, sectoral detail on emission sources and completeness of reporting are addressed for the legislative and regulatory regimes under which data are compiled. Where different inventories are compiled, a comparison and analysis of potential variations will be conducted, alongside uncertainty assessments.

For this purpose, the following inventories and data sources have been analysed in detail:

- National submissions of $\mathrm{NO}_{\mathrm{x}}$ and $\mathrm{NH}_{3}$ emission date to the EMEP programme

- National submissions of $\mathrm{N}_{2} \mathrm{O}$ emission data to the UNFCCC/IPCC

- The US National Emissions Inventory (NEI) dataset for $\mathrm{NO}_{\mathrm{X}}$ and $\mathrm{NH}_{3}$

- Inventory of US Greenhouse Gas Emissions and Sinks for $\mathrm{N}_{2} \mathrm{O}$

- The EDGAR global emission inventory dataset for $\mathrm{NO}_{\mathrm{x}}, \mathrm{NH}_{3}$ and $\mathrm{N}_{2} \mathrm{O}$ (version 4 representing the most up-to-date emissions; EDGAR Fast Track 32 and EDGAR HYDE for trends and for comparison purposes) 
- Literature data in particular for the China and for global/regional comparisons.

The datasets listed are openly accessible, in most cases directly online. The EDGAR v4 inventory (EDGAR, 2009) has only been partly published at this stage (greenhouse gases). However, the authors had access to a preliminary version of the dataset for air pollutants, which will be published in the near future, subject to error corrections to which the comparisons made in this paper may contribute (http://edgar.jrc.ec.europa.eu/). For an overview over all data sources and URLs, see Table 3.

On a global scale, the need for nitrogen management has been formulated in the 2004 Nanjing Declaration (Erisman 2004, UNEP 2004), which was presented to the United $\mathrm{Na}$ tions Environment Programme (UNEP) in Nanjing, China on October 16, 2004, with the aim to optimise nitrogen management in food and energy production on a local, regional and global scale.

\section{European emission inventories of reactive nitrogen species}

In Europe, emissions of ammonia and nitrogen oxides are covered by several regulatory regimes, both under the UNECE CLRTAP and directives of the European Commission. Member states of the European Union and parties to the protocols under the CLRTAP are subject to mandatory emission reporting. For the UNECE, the EMEP Centre on Emission Inventories and Projections (CEIP) at the Umweltbundesamt Vienna, Austria, hosts inventory datasets (both official submissions of signatories to the different protocols of the CLRTAP and emissions for modelling purposes) in an onlineaccessible database (http://www.ceip.at/).

Nitrous oxide on the other hand is not covered by the CLRTAP, but is required to be reported under the UNFCCC by Table 3 countries. The UNFCCC GHG inventory submissions can be accessed http://unfccc.int/ghg_emissions_data/ items/3800.php online.

In addition to these inventories which are generated based on obligatory reporting of national emissions, the EDGAR database provided global annual emissions per country and on a $1 \times 1$ degree grid for 1990 and 1995 for direct greenhouse gases $\mathrm{CO}_{2}, \mathrm{CH}_{4}, \mathrm{~N}_{2} \mathrm{O}$ and HFCs, PFCs and SF6 and the precursor gases $\mathrm{CO}, \mathrm{NO}_{\mathrm{x}}, \mathrm{NMVOC}$ and $\mathrm{SO}_{2}$. Similar inventories have been compiled for acidifying gases, $\mathrm{NH}_{3}$, $\mathrm{NO}_{\mathrm{x}}$ and $\mathrm{SO}_{2}$ and Ozone Depleting Gases (EDGAR v4 as well as EDGAR 3.2/FT 2000, see EDGAR, 2009). For this paper, the new EDGAR dataset version 4 ( $\mathrm{v} 4$ in the following text) is used, which has recently been (partly, for GHGs) officially released and of which a preliminary version was made available to the authors by the EDGAR team (http://edgar.jrc.ec.europa.eu/). EDGAR v4 (EDGAR, 2009) provides emissions for all relevant air pollutants and GHGs with an improved spatial resolution and until 2005.

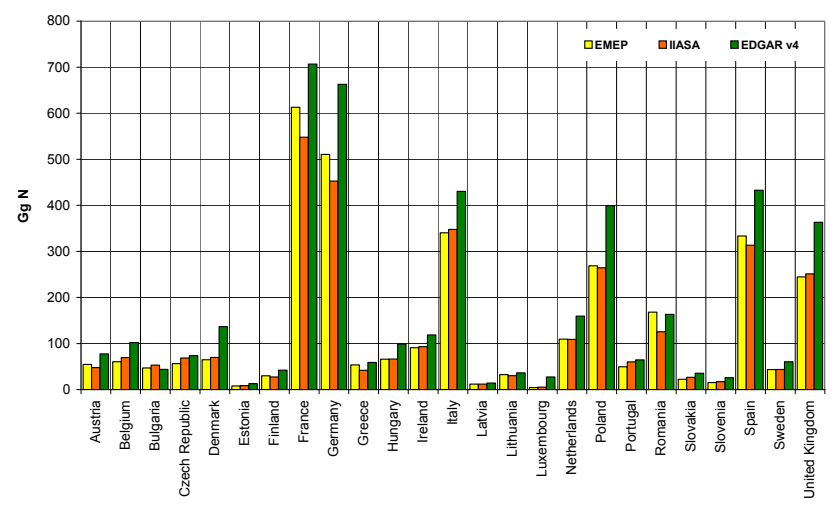

Fig. 1. Comparison of EU27 (not showing Malta and Cyprus) emissions of ammonia (expressed in $\mathrm{Gg} \mathrm{N}$ ) reported to EMEP and compiled by IIASA and the EDGAR v4 database for the year 2005. The slight differences between IIASA estimates and EMEP figures arise most likely from bilateral consultations with country experts, which led to corrections in agricultural emissions that had not (yet) been reflected in the EMEP inventories by recalculations of the year 2000 emissions submitted.

\subsection{Ammonia}

In the case of $\mathrm{NH}_{3}$, the vast majority of emissions from the 27 member states of the European Union (EU27) originate from agriculture (93\%), with some small contributions from waste management $(2.5 \%)$, industrial production processes $(2 \%)$ and road transport (1.8\%) (EMEP, 2009). This sectoral distribution is valid for most countries, with slight difference depending on the state of the art of agricultural production and, for instance, livestock intensity. For ammonia, a large number of non-agricultural sources contribute a small amount of emission (Sutton et al., 2000). Because the individual contributions are small for these sources (e.g. wild animals, direct emissions from humans, sewage management) many countries do not report emissions for all these terms. For example, detailed analysis of these non-agricultural emissions for the UK showed that they contribute around $15 \%$ of total ammonia emissions (Sutton et al., 2000; Dragosits et al., 2008). This is double the share noted above for the EU27 as a whole, which clearly indicates that a more comprehensive discussion of $\mathrm{NH}_{3}$ emissions and sources is needed.

Figure 1 illustrates that differences between the EMEP dataset and data used for model calculations with the GAINS model by IIASA (IIASA, 2009) are marginal for most countries. This was anticipated, as the EMEP emissions displayed represent official submissions by countries, which, in ultimately, form the basis for the IIASA data through a validation process by extensive bilateral consultations with country experts, often the same experts preparing the inventories reported to EMEP.

For some countries, however, the IIASA data are slightly different, with overall emissions for the EU27 being 4.4\% 


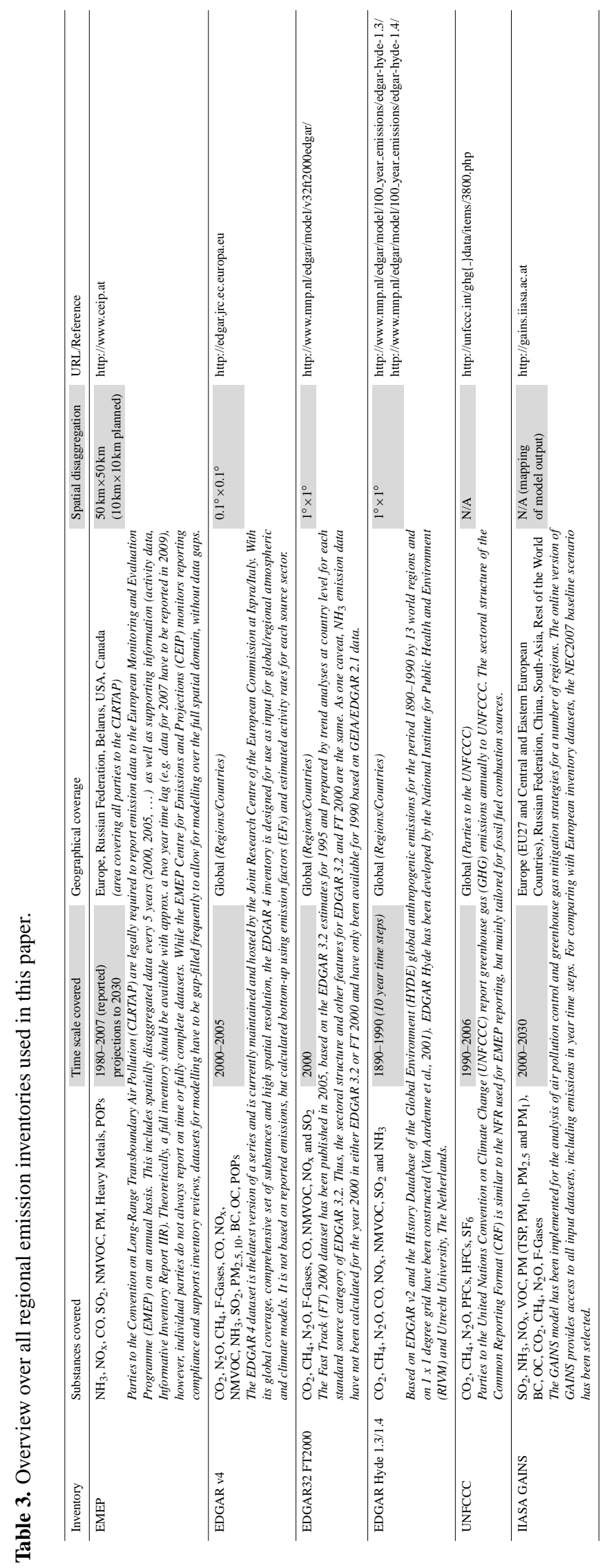


below the EMEP figures. The reason for this small difference in emissions that have the same underlying data sources is most likely revised animal numbers or more detailed emission calculations that have been available to the experts during the consultations, but have not yet been used to submit recalculated inventory figures to EMEP. The comparison with the EDGAR v4 dataset (EDGAR, 2009) shows that EDGAR emissions are (consistently) higher for the bulk of EU27 countries (32\%). As a major difference, the EDGAR emissions for agricultural sources are significantly higher than those reported to EMEP, with emissions from agricultural soils being most likely the main contributor to the difference observed. A more detailed analysis is not straightforward due the degree of completeness of EMEP emissions reported based on the current reporting format (Nomenclature for Reporting, NFR08), which distinguishes in sufficient detail emissions within the agricultural sector (currently available for 10 countries). An in-depth assessment is thus conducted for the case of the UK in Sect. 6.2.2.

For the European region, including the EU27, the accession countries (Turkey, FYR of Macedonia and Croatia), as well as Norway and Switzerland, the EMEP inventory amounts to $4.5 \mathrm{Tg}$ of $\mathrm{NH}_{3}$ for the year 2005 (3.3 Tg N). This is comparable with an estimate of $4.1 \mathrm{Tg} \mathrm{NH}_{3}$ for the whole of Europe made by Bouwman et al. (1997) for the year 1990 and an estimate of $5.3 \mathrm{Tg} \mathrm{NH}_{3}(4.3 \mathrm{Tg} \mathrm{N})$ by EDGAR (2009) for the same set of European countries. Galloway et al. (2004) only give a combined figure for Europe and the former Soviet Union (FSU), with atmospheric emissions of ammonia calculated at $8 \mathrm{Tg} \mathrm{N} \mathrm{yr}^{-1}$, with FSU emissions in 1990 at $3.4 \mathrm{Tg} \mathrm{N} \mathrm{yr}^{-1}$ according to the EDGAR dataset.

\section{$2.2 \quad$ Nitrogen oxides}

Nitrogen oxides have been the focus of significant emission control activities in recent decades, both for stationary sources (mainly large combustion plants) and mobile sources (especially road transport). In general it should be anticipated that $\mathrm{NO}_{\mathrm{x}}$ emission figures are less uncertain than those of $\mathrm{NH}_{3}$ or $\mathrm{N}_{2} \mathrm{O}$ and the initial comparison between EMEP and EDGAR datasets for 2005 confirms this with only slight differences for individual countries (see Fig. 2). Total $\mathrm{NO}_{\mathrm{x}}$ emissions (expressed as $\mathrm{NO}+\mathrm{NO}_{2}$ ) for Europe are estimated at $11.5 \mathrm{Tg} \mathrm{NO}_{\mathrm{x}}$ by both EDGAR v4 and EMEP (EDGAR, 2009; EMEP, 2009) for the year 2005 (3.5 Tg N).

This comparison indicates that $\mathrm{NO}_{\mathrm{x}}$ emissions are better understood than for instance $\mathrm{NH}_{3}$, in general. National totals do not display large variations between inventories; however, sectoral differences can be significant for individual countries. Issues such as an overall lack of measurement programmes, for instance for new vehicle technologies in road transport, and the uncertainties in the effects of decentralised power generation in a liberalised energy market on power plant emissions are likely to have an effect on the quality of $\mathrm{NO}_{\mathrm{x}}$ inventory datasets also in the future. For an in-depth

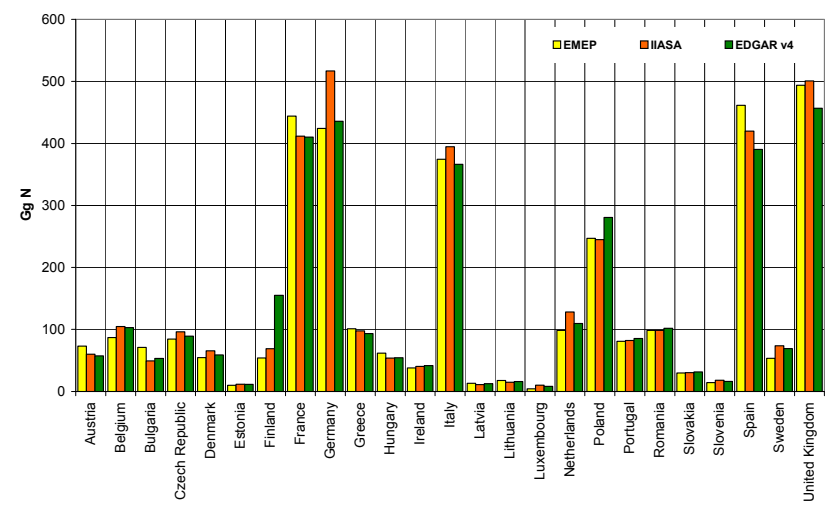

Fig. 2. Comparison of EU27 (not showing Malta and Cyprus) emissions of $\mathrm{NO}_{\mathrm{x}}$ (expressed as $\mathrm{Gg} \mathrm{N}$ ) reported to EMEP (EMEP, 2009) and presented in the EDGAR database (EDGAR, 2009) for the year 2005.

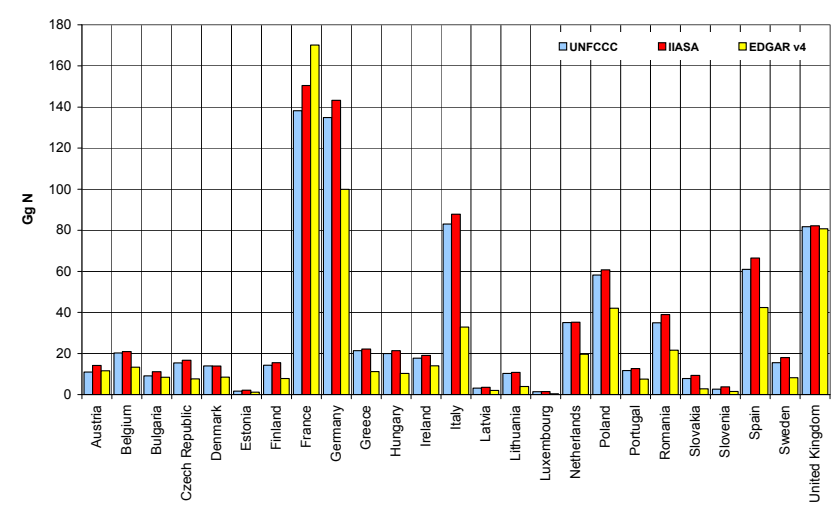

Fig. 3. Comparison of EU27 (not showing Malta and Cyprus) emissions of $\mathrm{N}_{2} \mathrm{O}$ (expressed as $\mathrm{Gg} \mathrm{N}$ ) reported to UNFCCC (without LULUCF, UNFCCC, 2009) and presented in the EDGAR v4 database (EDGAR, 2009) for the year 2005.

assessment of e.g. sectoral differences between inventories, up-to-date and documented national emission factors based on measurements for different technologies would be vital.

\subsection{Nitrous oxide}

Since $\mathrm{N}_{2} \mathrm{O}$ emissions are not reported under the CLRTAP, but subject to reporting obligations to the UNFCCC for Table 3 countries, the comparison is made between data collected under the UNFCCC and the EDGAR v4 inventory (Fig. 3).

For most countries, figures in both inventories are quite similar, with EDGAR showing an overall lower emission for the EU27 of about 24\%. For comparison, figures from the IIASA GAINS model are displayed in Fig. 3 as well. While EDGAR shows higher emissions or France (23\%), most other figures are substantially lower than UNFCCC data, for instance Finland $(-45 \%)$, Italy $(-60 \%)$ or Sweden $(-47 \%)$. At this stage, it is difficult to assess fully 


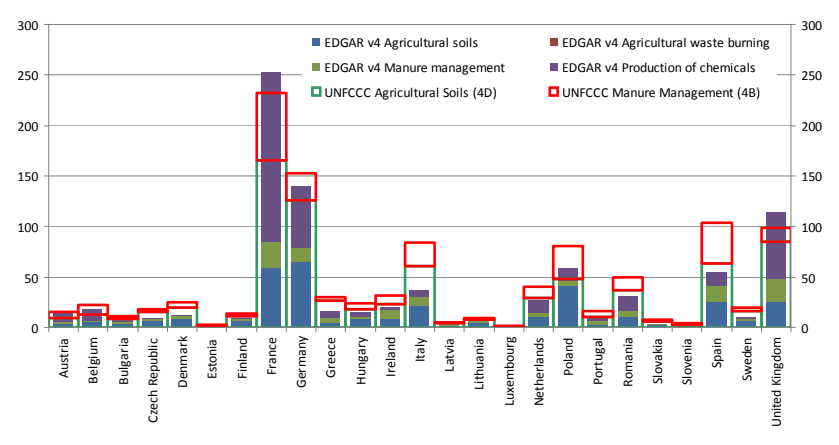

Fig. 4. Relative contributions of $\mathrm{N}_{2} \mathrm{O}$ emissions (in $\mathrm{Gg} \mathrm{N}_{2} \mathrm{O}$ ) from agricultural sources soils and manure management in the EU27 countries (not displaying Cyprus and Malta) according to the EDGAR v4 inventory (EDGAR, 2009) and compared to major agricultural sources as reported to UNFCC (Agricultural Soils, NRF 4D; Manure Management, NRF 4B) (UNFCCC, 2009).

the uncertainty in either dataset, but it should be stated that recent findings of Skiba et al. (2001) provide a methodology for the calculation of $\mathrm{N}_{2} \mathrm{O}$ emissions from soils, one of the main sources of $\mathrm{N}_{2} \mathrm{O}$, which results in higher emissions than the current UNFCCC established methodology. Within the EU27, $48 \%$ of $\mathrm{N}_{2} \mathrm{O}$ emissions in the EDGAR v4 inventory stem from agricultural sources $(34.2 \%$ from agricultural soils, $13.9 \%$ from manure management and $0.1 \%$ from agricultural waste burning). Shares of emissions from agricultural soils in individual countries vary significantly, between 9.6\% (Greece) and 67.6\% (Denmark). Figure 4 highlights the variation of relative contributions of agricultural soils and manure management to $\mathrm{N}_{2} \mathrm{O}$ emissions in the EU27 countries for a comparison between EDGAR v4 and UNFCCC. A third contributing source to $\mathrm{N}_{2} \mathrm{O}$ emissions in the EU27 is the chemical industry sector, contributing about $28 \%$ of total $\mathrm{N}_{2} \mathrm{O}$ emissions in 2005 in EDGAR v4. It is likely that emissions from the chemical industry are well understood and hence emission factors and activity rates can be assumed to be less uncertain than those from agricultural soils or manure management. Hence, the differences between UNFCCC and EDGAR data most likely mainly arise from the application of different emission factors (or activity rates) in these two sectors.

Figure 4 illustrates the difference between the main sources of $\mathrm{N}_{2} \mathrm{O}$ emissions with a focus on emissions from agricultural sources. There is a clear indication that emissions reported to UNFCCC under CRF (Common Reporting Format) categories 4B (Manure Management) and 4D (Agricultural Soils) are substantially higher than those estimated in EDGAR v4 under the same headings.

However, even in those cases were both inventories provide similar figures, a more thorough investigation of emissions from agricultural soils may be required in the light of the findings of Skiba et al. (2001), Crutzen et al. (2008) and Mosier et al (1998), which indicate a potential underestima- tion of $\mathrm{N}_{2} \mathrm{O}$ emissions from soils in current inventories. The increasing demand for bio fuels could even lead to a larger underestimation, unless future emission factors take these findings into account.

\section{Emission inventories of reactive nitrogen species in the United States of America}

The US Environmental Protection Agency is charged with developing the National Emission Inventory (NEI, US EPA, 2009a) in support of the Clean Air Act and subsequent amendments. The NEI includes an accounting of pollutants that impact air quality, including $\mathrm{NO}_{\mathrm{x}}$ and $\mathrm{NH}_{3}$. These efforts have recently been reviewed in an assessment report by NARSTO (2005). In addition, the EPA prepares an estimate of $\mathrm{N}_{2} \mathrm{O}$ emissions in the US Inventory of Greenhouse Gas Emissions and Sinks (US EPA, 2009b), in accordance with the UNFCCC.

\subsection{Ammonia}

The NEI estimates that more than $80 \%$ of total USA ammonia emissions are from livestock manure management and application of chemical fertilizers. The next largest source is ammonia from vehicles equipped with catalytic converters, which comprises approximately $7 \%$ of the inventory. While the NEI and EDGAR database have similar total agricultural and vehicle emissions, $14 \%$ of the EDGAR $\mathrm{NH}_{3}$ emissions are from industrial combustion, while this source is less than $1 \%$ in the NEI.

Because of the operational challenges in measuring ammonia emissions and a lack of detailed animal husbandry practices data, ammonia emission estimates have high uncertainty. Independent efforts to quantify the seasonal variability have shown agreement for winter and summer emissions, but differ for the spring and fall (Gilliland et al., 2006: Pinder et al., 2006: Henze et al., 2008). Because atmospheric agricultural emissions are rarely regulated, the trend in emissions is expected to be proportional to the increase in livestock population and acres under cultivation. Both are expected to increase in coming years (USDA, 2007).

\subsection{Nitrogen oxides}

The NEI estimates that the largest contributors of US $\mathrm{NO}_{\mathrm{x}}$ emissions include on-road vehicles $(32 \%)$, off-road vehicles (30\%), such as ships, aircraft, and construction equipment, and electricity and industrial power generation (27\%). Emissions from on-road and off-road vehicles are calculated using the National Mobile Inventory Model (NMIM) (http://www.epa.gov/otaq/nmim.htm). While not used in this study, a more advanced mobile source emissions model, MOVES (http://www.epa.gov/otaq/models/moves/), is currently under development and a draft version is available for public use. Important improvements include more detailed 


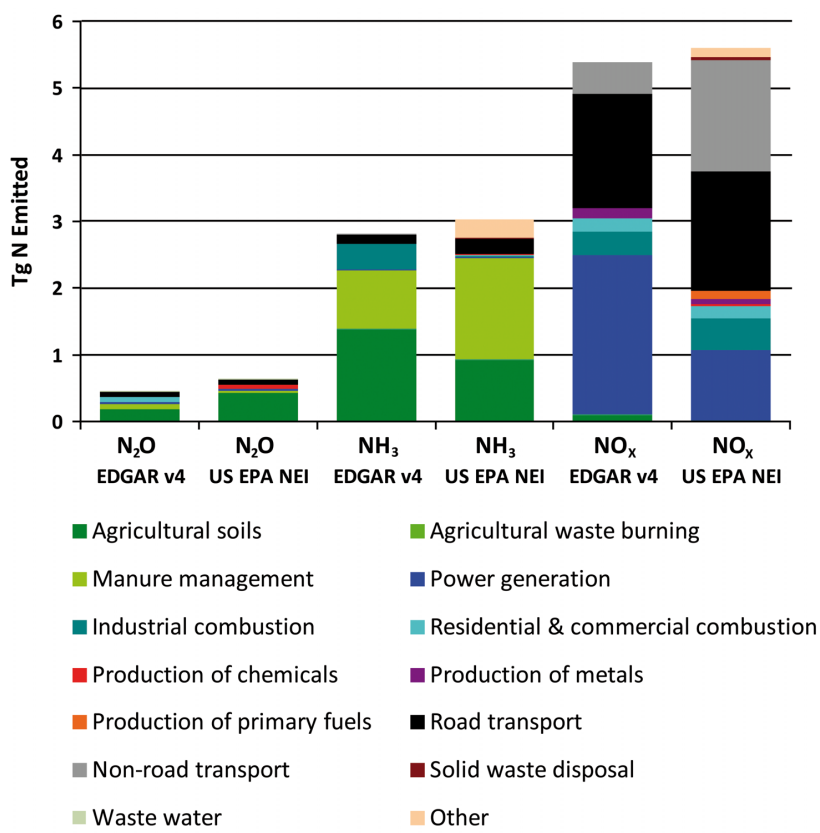

Fig. 5. Comparison of US EPA emissions of $\mathrm{N}_{2} \mathrm{O}, \mathrm{NH}_{3}$, and $\mathrm{NO}_{\mathrm{x}}$ with the EDGAR database for the year 2005 (USEPA, 2009a, b; EDGAR, 2009).

inspection and maintenance data and better representation of extended idling emissions.

Despite increased diesel and gasoline consumption, $\mathrm{NO}_{\mathrm{x}}$ emissions from on-road sources are estimated to have decreased by on average $5 \%$ per year since 2002 due to the introduction of stricter emission standards. Parrish (2006) used ambient data to show that total on-road emissions may have increased from 1990-2000; however, in a multi-city, multi-year study, Bishop and Stedman (2008) have demonstrated that per-car emission factors have decreased from 2000 to 2006. The NEI reports little year-to-year change in off-road vehicle emissions. Many electricity and industrial power generation facilities have been subject to several recent regulated emission reductions including the $\mathrm{NO}_{\mathrm{x}}$ Budget Trading Program. Because most of these facilities are equipped with Continuous Emission Monitors, the emission magnitude and trend is well quantified. Since 1999, this sector has reduced emissions by an average of $6.4 \%$ per year. The combined effect of the reductions in mobile and stationary source $\mathrm{NO}_{\mathrm{x}}$ emissions has been observed in the surface concentration monitoring data (Godowitch et al., 2008) and from space-based remote sensing methods (Kim et al., 2006; Kim et al., 2009).

In Fig. 5, EDGAR v4 and US EPA $\mathrm{NO}_{\mathrm{x}}$ emission data are aggregated by sector to make them directly comparable. Where stationary combustion sources are concerned, EDGAR has markedly larger emissions. The NEI power generation emission rates are likely more accurate since they are measured at the electricity generating units as part of the Continuous Emission Monitoring System. Road transport emissions are similar in both datasets, but interestingly non-road mobile sources (which include off-road vehicles, rail, air and shipping) are significantly larger in the US EPA dataset. The NEI partially includes international shipping emissions near the US coast, which have been omitted from the EDGAR inventory and have been estimated in EDGAR FT32 at about $0.43 \mathrm{Tg} \mathrm{N}$ for the US in the year 2000. Another possible explanation is a difference in activity rates and/or emission factors for domestic air transport. From 2000 to 2005 , the trends in these two databases also differ. For onroad sources, EDGAR estimates $6 \% \mathrm{yr}^{-1}$ reduction (NEI: $4 \% \mathrm{yr}^{-1}$ ), but for power generation and industrial sources, the EDGAR inventory has little trend (NEI: $6 \% \mathrm{yr}^{-1}$ reduction).

\subsection{Nitrous oxide}

Total US $\mathrm{N}_{2} \mathrm{O}$ emissions for 2005 are estimated to be $1.02 \mathrm{Tg} \mathrm{N}_{2} \mathrm{O}$ (US EPA, 2009b). The largest source of US $\mathrm{N}_{2} \mathrm{O}$ emissions is agricultural soils $(67 \%)$, followed by fossil fuel combustion in vehicles $(12 \%)$, industrial processes $(8 \%)$, fossil fuel combustion for electricity generation $(5 \%)$ and livestock manure management (4\%). Enhancements of $\mathrm{N}_{2} \mathrm{O}$ emissions from agricultural soils include practices such as fertilization, application of livestock manure, grazing animals on pasture or feedlots, and cultivation of $\mathrm{N}$-fixing crops. The estimated trend in $\mathrm{N}_{2} \mathrm{O}$ emissions for the USA is a gradual reduction of approximately $1 \%$ per year since 2000 . This is due to a $5 \%$ reduction per year in the emissions from vehicles and industrial processes - the other sectors are estimated to have largely remained constant over this period. EDGAR $\mathrm{v} 4$ emissions are lower than those reported by EPA. This is almost entirely due to lower emissions from agricultural soils in the EDGAR v4 inventory.

The physical and chemical processes that drive emissions of $\mathrm{NH}_{3}, \mathrm{NO}_{\mathrm{x}}$, and $\mathrm{N}_{2} \mathrm{O}$ are often intertwined. This is also true for the human activities that cause these emissions, such as fuel combustion in motor vehicles and agricultural land under cultivation. However, the GHG emission inventory and the NEI do not always use the same models and data sources. For example, direct fertilized crop emissions of $\mathrm{N}_{2} \mathrm{O}$ are estimated using the DAYCENT model (Del Grosso et al., 2001), while the temporal pattern of $\mathrm{NH}_{3}$ emissions are estimated using an emission factor approach (Goebes et al., 2003), and NO emissions are calculated using the BEIS model (http://www.epa.gov/asmdnerl/biogen.html). Because the interactions between these processes are not explicitly considered, these shortcomings impede efforts to devise strategies that simultaneously mitigate climate change and improve air quality. 


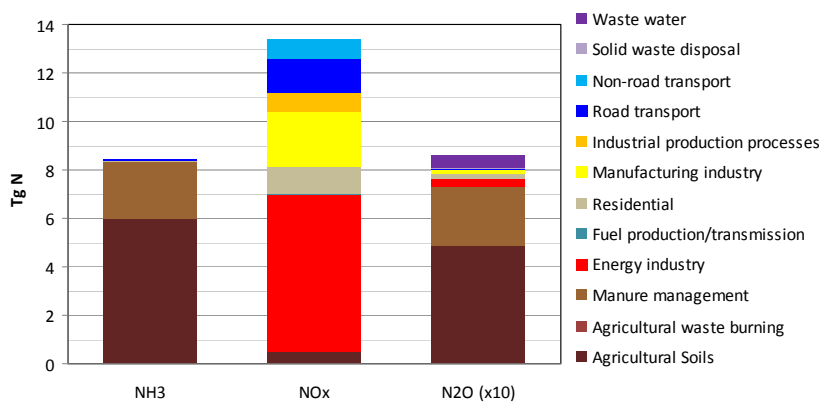

Fig. 6. Emissions of $\mathrm{NH}_{3}, \mathrm{NO}_{\mathrm{x}}$ and $\mathrm{N}_{2} \mathrm{O}$ (expressed in $\mathrm{Tg} \mathrm{N}$ ) for the China in 2005 according to the EDGAR v4 inventory (EDGAR, 2009) for the main emitting source sectors. $\mathrm{N}_{2} \mathrm{O}$ emissions are increased by a factor of 10 for ease of comparison.

\section{Emission inventories of reactive nitrogen species in China}

The analysis of the emission situation in China is comparatively more difficult than is the case for Europe or the United States. Reasons for this are, among others, the immense growth rates of the economy and thus fast developing emission sources, the lack of an official national inventory programme and no reporting of emissions to international organisations. Figure 6 displays the emission estimates for the year 2005, distinguishing the main source sectors. $\mathrm{NH}_{3}$ and $\mathrm{N}_{2} \mathrm{O}$ emissions are here dominated by agricultural sources (mainly agricultural soils and manure management), while for $\mathrm{NO}_{\mathrm{x}}$, the main difference to Europe and the US is the large share of stationary combustion relative to mobile sources. In the following sections, recent studies are discussed for each of the substances.

\subsection{Ammonia}

Only a few studies on ammonia emissions in China are available (e.g. Zhao et al., 1994; Yan et al., 2003). With regard to total $\mathrm{NH}_{3}$ emissions in China, the major contribution comes from $\mathrm{N}$-fertilizer application (52\%) and livestock (41\%) respectively in the 1990's (Klimont, 2001a). Other sources of ammonia emissions include biomass burning, natural ecosystems, crops and oceans, humans (breath, sweat, excretion) and fossil fuel combustion.

The basic methodology applied to derive these emissions relies on the approach used in Europe (Klaassen, 1994; Klimont, 2001b), and as far as available takes into account information about China-specific characteristics. Klimont (2001a) estimated the total ammonia emissions in China at 9.7 $\mathrm{Tg} \mathrm{NH}_{3}$ in $1990\left(11.7 \mathrm{Tg} \mathrm{NH}_{3}\right.$ in 1995), which translates into $7.98 \mathrm{Tg} \mathrm{N}$ (1990) respectively $9.62 \mathrm{Tg} \mathrm{N}$ (1995). Emissions were as well spatially disaggregated on a $1^{\circ} \times 1^{\circ}$ grid for both years. In 1995 the highest ammonia emission density, exceeding $100 \mathrm{Gg} \mathrm{NH}_{3}$ per grid, is observed in Jiangsu and Henan provinces. This corresponds well with the large population of pigs in these regions as well as high cattle density in Henan province. Using the IPCC approach, $\mathrm{NH}_{3}$ emission from synthetic fertilizer and manure application in 1990 was estimated to be $1.65 \mathrm{Tg} \mathrm{N}$ by Li Yu'e et al. (2000). Yan et al. (2003) quantified the use of urea and ammonium bicarbonate and the cultivation of rice leading to a high average ammonia loss rate from chemical $\mathrm{N}$ fertilizer in East, Southeast and South Asia, and the total emission was estimated to be $5.8 \mathrm{Tg} \mathrm{N}$ for the area of China. These values compare reasonably well with the amount of $8.4 \mathrm{Tg} \mathrm{N}$ from $\mathrm{NH}_{3}$ emissions for China in EDGAR v4, with $6.01 \mathrm{TgN}$ $(72 \%)$ stemming from agricultural soils and $2.29 \mathrm{Tg} \mathrm{N}(27 \%)$ from manure management.

Due to anticipated increases in synthetic fertilizer application rates and per-capita meat and dairy consumption, future ammonia emissions are expected to continue to rise.

\subsection{Nitrogen oxides}

East Asia is a region of the world with large and rapidly increasing anthropogenic emissions, $\mathrm{NO}_{\mathrm{x}}$ emissions have increased by $58 \%$ from $1975\left(2.05 \mathrm{Tg} \mathrm{N} \mathrm{yr}^{-1}\right)$ to 1987 (3.25 Tg N yr${ }^{-1}$ ) (Kato and Akimoto, 1992), and Van Aardenne et al. (1999) anticipated an almost fourfold increase in $\mathrm{NO}_{\mathrm{x}}$ emissions for the period from 1999 to 2020 . Especially in China, anthropogenic emissions associated with fossil fuel combustion have grown significantly due to a period of rapid economic development and industrial expansion in the last three decades (e.g., Streets and Waldhoff, 2000).

Using data from the China Statistical Yearbook (Press, 1996), Akimoto et al. (1994) and Kato and Akimoto (1992) estimated $\mathrm{NO}_{\mathrm{x}}$ emissions in China for the year 1987. Bai (1996) considered that the inventory should be based on more detailed data than available from the Yearbook, and the emission factors should be modified to be consistent with actual emission factors applicable to the situation in China. Bai (1996) provided a $\mathrm{NO}_{\mathrm{x}}$ emission inventory for the year 1992 using more detailed data from statistical yearbooks on a provincial level and emission factors measured in Chinese installations.

Bai (1996) created a spatially disaggregated inventory on $1^{\circ} \times 1^{\circ}$ with the highest grid value being $>0.1 \mathrm{Tg} \mathrm{Nyr}^{-1}$, which occurred only in Shanghai. From the east to the west of China, the values decreased. The emissions in some provinces such as Inner Mongolia, Qinghai and Tibet are even $<0.0001 \mathrm{Tg} \mathrm{Nyr}^{-1}$, which is consistent with the distribution of industrial installations and population between these regions.

The rapid growth of $\mathrm{NO}_{\mathrm{x}}$ emissions in China (Bai, 1996; Ma and Zhou, 2000; Streets et al., 2000), with an increase from $9.5 \mathrm{Tg}$ to $12.0 \mathrm{Tg}$ (calculated as $\mathrm{NO}_{2}$ ) between 1990 and 1995 is driven by a significant increase in emissions from the transport sector (increase of 62\%). Emissions also increase significantly in the industrial, power generation and 
domestic sectors, with increases of $26 \%, 20 \%$ and $21 \%$, respectively. Within these sectors, emissions from industrial installations were the largest individual source group, contributing approx. $42 \%$ of total emissions $\left(5.0 \mathrm{Tg} \mathrm{NO}_{\mathrm{x}}\right.$ as $\mathrm{NO}_{2}$ ). From 1995 to 2000, some studies (e.g., Aardenne et al., 1999; Streets et al., 2000) estimated that $\mathrm{NO}_{\mathrm{x}}$ emissions in China will continue to grow rapidly. However, other researches' results using more recent statistical data (e.g., Tian et al., 2001) indicate that $\mathrm{NO}_{\mathrm{x}}$ emissions began to remain somewhat stable for a few years with total emissions in China amounting to $11.3 \mathrm{Tg} \mathrm{NO}_{\mathrm{x}}\left(\right.$ as $\mathrm{NO}_{2}$ ) in $1995,12.0 \mathrm{Tg}$ (1996), $11.7 \mathrm{Tg}$ (1997) and $11.2 \mathrm{Tg}$ (1998). In the analysis by Tian et al., this is explained on the basis of changing energy management in China. However, for the same time period (1995-2000), Ohara (2007) and IIASA (2009) estimated a slow increase of emissions from $9.31 \mathrm{Tg} \mathrm{NO}_{\mathrm{x}}$ to $11.19 \mathrm{Tg} \mathrm{NO}_{\mathrm{x}}$ (Ohara, 2007), respectively $9.38 \mathrm{Tg} \mathrm{NO}_{\mathrm{x}}$ to $11.73 \mathrm{Tg} \mathrm{NO}_{\mathrm{x}}$ (IIASA, 2009), all calculated as $\mathrm{NO}_{2}$ (see as well Fig. 9 for the development over the whole period).

According to Streets et al. (2003) Chinese emissions in the year 2000 have only slightly increased $\left(11.3 \mathrm{Tg}_{\mathrm{NO}}\right)$. For the year 2005, however, both EDGAR (2009) and IIASA (2009) estimate further increases to $18.35 \mathrm{Tg} \mathrm{NO}_{\mathrm{x}}\left(\right.$ as $\left.\mathrm{NO}_{2}\right)$ and 17.09 $\mathrm{Tg} \mathrm{NO}_{\mathrm{x}}\left(\right.$ as $\left.\mathrm{NO}_{2}\right)$ respectively. Based on EDGAR (2009), power generation still contributes the lion's share of $\mathrm{NO}_{\mathrm{x}}$ emissions in China (48\%), while road transport is still comparatively low at $11 \%$. In addition to that, satellite observations of the tropospheric $\mathrm{NO}_{2}$ column density over Eastern China have increased considerably during 1996 to 2004 (Richter et al., 2005; van der A et al., 2006), suggesting large emission increases over that period

\subsection{Nitrous Oxide}

The UNDP/GEF ECPINC Project (Enabling China to Prepare Its Initial National Communication, http://www. ccchina.gov.cn/en/NewsInfo.asp?NewsId=5392) has been implemented to support China in fulfilling its commitments under the UNFCCC to communicate to the Conference of Parties to the Convention (1) a national inventory of emissions and sinks of greenhouse gases (2) a general description of steps taken or envisaged by China to implement the Convention and (3) any other information China considers relevant and suitable for inclusion in its Communication.

A fair amount of research has been conducted on an $\mathrm{N}_{2} \mathrm{O}$ emissions inventory for China. Zheng et al. (2004) have shown that most (up to 75\%) of cropland $\mathrm{N}_{2} \mathrm{O}$ emissions are direct emissions: immediately from fertilized top-soil rather than denitrification of nitrate leached into sub-surface and groundwater. Zheng et al. (2004) collected 54 direct $\mathrm{N}_{2} \mathrm{O}$ emission factors $\left(\mathrm{EF}_{d}^{\prime} \mathrm{s}\right)$ obtained from 12 sites of Chinese croplands and found that of these $60 \%$ are underestimated by $29 \%$ and $30 \%$ are overestimated by $50 \%$ due to observation shortages. The biases of $\mathrm{EF}_{d} \mathrm{~s}$ are corrected and their uncertainties are re-estimated. Of the 31 site-scale $\mathrm{EF}_{d} \mathrm{~s}$,
$42 \%$ are lower by $58 \%$ and $26 \%$ are higher by $143 \%$ than the IPCC default values. Periodically wetting/drying the fields or doubling nitrogen fertilizers may double or even triple an $\mathrm{EF}_{d}$. The direct $\mathrm{N}_{2} \mathrm{O}$ emissions from Chinese croplands are estimated at $275 \mathrm{Gg} \mathrm{N}_{2} \mathrm{O}-\mathrm{N}$ yr ${ }^{1}$ in the $1990 \mathrm{~s}$, of which $20 \%$ is due to vegetable cultivation. The great uncertainty of this estimate, $-79 \%$ to $135 \%$, is overwhelmingly due to the huge uncertainty in estimating $\mathrm{EF}_{d} \mathrm{~s}(-78 \pm 15 \%$ to $129 \pm 62 \%$ ). The direct $\mathrm{N}_{2} \mathrm{O}$ emission intensities significantly depend upon the economic situation of the region, implying a larger potential emission in the future.

However, agricultural activity is the main, but not the only source of $\mathrm{N}_{2} \mathrm{O}$ emissions in China. According to results by $\mathrm{Li}$ Yu'e et al. (2000), total $\mathrm{N}_{2} \mathrm{O}$ emissions from stationary fuel combustion amounted to $58.22 \mathrm{Gg} \mathrm{N} \mathrm{yr}^{-1}$ in 1990 in China. Within the fuel combustion sector, energy industries, manufacturing industries and residential areas were the main sources of $\mathrm{N}_{2} \mathrm{O}$. Among fossil fuels, hard coal was the main contributor to $\mathrm{N}_{2} \mathrm{O}$ emissions. The industrial process sector was a less critical source of $\mathrm{N}_{2} \mathrm{O}$ emissions, with the total $\mathrm{N}_{2} \mathrm{O}$ emissions from this source group amounting to $0.41-$ $0.90 \mathrm{Gg} \mathrm{N} \mathrm{yr}^{-1}$. The total emission of $\mathrm{N}_{2} \mathrm{O}$ as a result of fertilizer application was $342.5 \mathrm{Gg} \mathrm{N} \mathrm{yr}^{-1}$ in 1990 , being the most important contributor to $\mathrm{N}_{2} \mathrm{O}$ emission from agricultural soils.

While both Li (2000) and Xing's (1998) estimations did not consider permanent croplands, Lu et al (2006) established an empirical model to develop a spatial inventory at the $10 \times 10 \mathrm{~km}$ scale of direct $\mathrm{N}_{2} \mathrm{O}$ emissions from agriculture in China, in which both emission factor and background emission for $\mathrm{N}_{2} \mathrm{O}$ were adjusted for precipitation. As a result, the total annual fertilizer-induced $\mathrm{N}_{2} \mathrm{O}$ emission

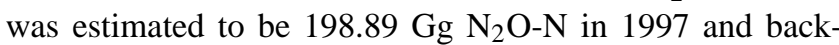
ground emissions of $\mathrm{N}_{2} \mathrm{O}$ from agriculture was estimated to be $92.7 \mathrm{Gg} \mathrm{N}_{2} \mathrm{O}-\mathrm{N}$ and the annual $\mathrm{N}_{2} \mathrm{O}$ emission totalled $291.67 \mathrm{Gg} \mathrm{N}_{2} \mathrm{O}-\mathrm{N}$. All $\mathrm{N}_{2} \mathrm{O}$ emission measurements are subject to significant uncertainty due to their great temporal and spatial variations of cropland fluxes.

For the years 2000 and 2005, EDGAR (2009) estimates $928 \mathrm{Gg} \mathrm{N}_{2} \mathrm{O}$ (2000) and $1065 \mathrm{Gg} \mathrm{N}_{2} \mathrm{O}$ (2000). This is consistently lower than figures by IIASA (2009), with $1,747 \mathrm{Gg} \mathrm{N}_{2} \mathrm{O}$ (2000) and $1,854 \mathrm{Gg} \mathrm{N}_{2} \mathrm{O}$ respectively. It has to be noted, that EDGAR 32 FT 2000 had estimated $\mathrm{N}_{2} \mathrm{O}$ emissions for China at $1764 \mathrm{Gg} \mathrm{N}_{2} \mathrm{O}$, which is comparable with IIASA (2009) for that year, but almost twice the amount of what EDGAR (2009) states. One possible explanation for this is the inclusion of sources such as run-off and leaching, forest and shrub fires in EDGAR 32 FT 2000, which are not included in the figures presented here for EDGAR v4. 


\section{Evaluation of emission inventories for reactive nitro- gen}

\subsection{Uncertainty assessment in general}

For all emission inventories portrayed here, the assessment of uncertainties is a key aspect. For national inventories, issues of compliance or non-compliance with reduction targets and emission ceilings are relevant, while in general the quantification of uncertainties of emissions as input data for atmospheric dispersion models is of importance. Aspects of completeness regarding the total amount of emissions accounted for are as important as the spatial distribution, chemical composition and temporal patterns of emission occurrences.

Within the context of emission inventories compiled under the CLRTAP, country submissions are accompanied by so-called informative inventory reports (IIRs, http://www. emep.int/emis2007/reportinginstructions.html), covering aspects of completeness, an analysis of key sources and uncertainties. In addition to this, regular centralised reviews are conducted for selected countries, with the aim to improve the quality and accuracy of reported emission data. For the United States, NARSTO's third assessment report Improving Emission Inventories for Effective Air Quality Management Across North America: A NARSTO Assessment (NARSTO, 2005) took stock of the current state of emission inventories for Canada, the United States and Mexico and identified areas for improvement.

Under the UNFCCC, emission reporting is guided by a document called "Good Practice Guidance and Uncertainty Management in National Greenhouse Gas Inventories" (http: //www.ipcc-nggip.iges.or.jp/public/gp/english/, see as well IPCC 1997, 2000) in order to "...to assist countries in producing inventories that are neither over nor underestimates so far as can be judged, and in which uncertainties are reduced as far as practicable."

These formalised assessments of inventories are relevant sources of information when trying to identify the overall accuracy of emission estimates, for instance, on a national scale or across countries for individual pollutants. In addition, studies such as conducted by Winiwarter and Rypdal (2001) and Rypdal and Winiwarter (2001) provide a methodological analysis of uncertainties for specific trace gases, respectively individual countries. An analysis conducted by Olivier et al. (1999) discusses in detail uncertainties of GHG emissions on a sector level, distinguishing between uncertainties in activity datasets, emission factors (as the main drivers of uncertainties in inventories) and the resulting total emissions.

Olivier et al. (1999) conclude that emissions from fossil fuel production and combustion are generally well understood and prone to small to medium uncertainties only. This can be said as well for industrial production processes or solvent use. In contrast, emissions related to agricultural landuse are viewed as significantly more uncertain. In a similar way, emission estimates of $\mathrm{N}_{2} \mathrm{O}$ and $\mathrm{CH}_{4}$ are generally less robust, because $\mathrm{CO}_{2}$ is emitted from combustion processes mainly can be calculated more accurately than emissions based on soil microbial processes for instance. These findings have implications as well for the discussion of the different substances in the inventories analysed in this paper, where $\mathrm{NO}_{\mathrm{x}}$ emissions can be seen comparatively robust. Yet, the uncertainty associated with $\mathrm{NO}_{\mathrm{x}}$ emissions is approx. 4 times higher than for $\mathrm{CO}_{2}$ emissions, because these are directly linear to fuel input in combustion sources and EFs are not influenced by processes and hence easier to determine. On the other hand, $\mathrm{NH}_{3}$ and even more so, $\mathrm{N}_{2} \mathrm{O}$ emissions are likely to be more uncertain because their main sources are related to agriculture and affected e.g. by soil biochemical processes and meteorological and climatological drivers.

For individual inventories, e.g. the UK NAEI, uncertainty assessments are provided by inventory compilers (http://www.naei.org.uk/emissions/emissions_2007.php? action=notes1). For $\mathrm{NO}_{\mathrm{x}}$, the NAEI assumes $\pm 7 \%$, for $\mathrm{NH}_{3} \pm 20 \%$, while for $\mathrm{N}_{2} \mathrm{O}$ no individual assessment is made, but an overall uncertainty of $\pm 15 \%$ is estimated across the 6 greenhouse gases overall.

Following the differences in sectoral uncertainties provided by Olivier et al. (1999), the following sections will specifically investigate differences in sectoral emissions between inventories in order to identify, if current inventory differences are within range of the uncertainty estimates.

\subsection{Inventory comparison - analysing differences and similarities}

\subsubsection{General observations for the situation in Europe}

A full and detailed intercomparison of the inventories on the most detailed sectoral level for all countries/regions is beyond the scope of this paper. However, some similarities and differences are worth noting. In the case of ammonia, both the EMEP and the IIASA figures are quite similar, with some countries showing different emission levels, most likely due to recalculations and re-assessments of e.g. animal numbers that have been emerging in the course of bilateral consultations in the preparation of the IIASA dataset and which have not (yet) been incorporated in recalculations of the data reported to EMEP.

With regard to $\mathrm{NO}_{\mathrm{x}}$, the differences between EMEP and EDGAR figures are substantial for some countries and remarkably different in total (EDGAR v4 32\% higher than EMEP). Some of the potential sources of these discrepancies have been highlighted in Sect. 3.3, in particular the different sectoral allocations including some emission sources that are not reported under EMEP in the EDGAR dataset.

In addition to that, a likely reason for these large differences are assumptions regarding underlying emission factors for some of the largest contributing sources, e.g. due to the estimated share of power plants equipped with efficient $\mathrm{NO}_{\mathrm{x}}$ 


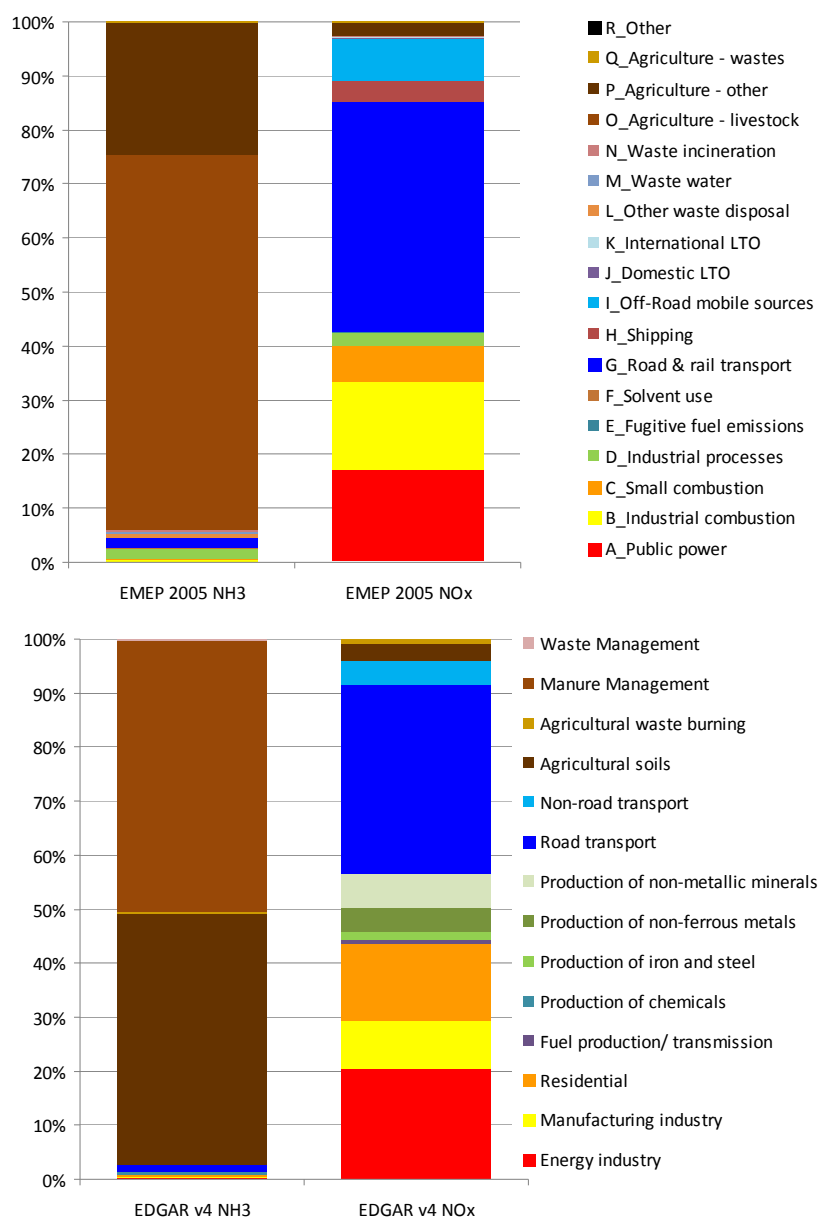

Fig. 7. Sectoral comparison of emissions for the year 2005 between EMEP (top; EMEP, 2009) and EDGAR v4 (bottom; EDGAR, 2009) for the EU27 countries (excluding Malta and Cyprus). It should be noted, that the EMEP sectoral split is based on only 10 countries reporting according to the latest sectoral structure (NFR 08, Level 1), which is best comparable with the EDGAR v4 sector structure.

control equipment, or emission factors and activity rates for road transport sources.

Figure 7 displays a direct comparison of $\mathrm{NH}_{3}$ and $\mathrm{NO}_{\mathrm{x}}$ emissions in the EMEP and the EDGAR v4 inventories by sector for the year 2005. The most recent change in EMEP reporting requirements, adopting a new reporting format termed NFR 08 (Nomenclature for Reporting 2008) which is - even on an aggregated level - better suited for sectoral analysis than its predecessors (e.g. NFR 01, NFR 02) which were based on the UNFCCC CRF format and in some areas lacking a sufficient level of detail. With regard to $\mathrm{NH}_{3}$, agricultural emissions show a similar pattern in both inventories overall and are dominating emissions for this substance. The situation for $\mathrm{NO}_{\mathrm{x}}$ emissions is more diverse and shows a distinct difference for stationary combustion sources, which contribute more than $55 \%$ to EDGAR v4 $\mathrm{NO}_{\mathrm{x}}$ emissions, but only account for about $42 \%$ of EMEP $\mathrm{NO}_{\mathrm{x}}$ emissions. A full comparison of individual sectors by country on a European scale would be worthwhile once all countries are reporting emissions based on the new NFR 08 sectoral structure. As this is not feasible at this stage and within the scope of this paper, an analysis is conducted for the United Kingdom in the following section.

\subsubsection{Detailed analysis for the United Kingdom}

For a thorough investigation of the differences between inventories, it is essential to have access to a very detailed sectoral split, and if feasible, even the emission factors and activity rates that have been used to compile the inventories. In this context, the structure initially applied in the EMEP inventories labelled SNAP (Selected Nomenclature for Air Pollution, EMEP) provided emission data with a detailed level 3 split allowed for a comparison down to process and fuel level. However, not many countries provided the obligatory information in this detailed split and hence inventories were subject to different levels of detail and substantial gaps. The new format for reporting under EMEP has been termed Nomenclature for Reporting (NFR, current version is NFR 08). While NFR has been closely aligned with the UNFCCC common reporting format (CRF) and thus been mainly driven by fossil fuel combustion sources, it provided less detail and no distinctions had been made for instance with regard to the type of fuel used in power plants or road transport modes. The recently adopted NFR 08 better accounts for non-combustion sources and already on the most aggregated level (NFR 08, Level 1) provides a useful split into the main sectors (for details on NFR 08, see http://www.unece.org/env/documents/2008/EB/EB/ ece.eb.air.2008.4.e.pdf). The sectoral split used in EDGAR $\mathrm{v} 4$ reflects the bottom-up character of the inventory. It is not always directly comparable to NFR sectors, but in most cases, an equivalent source sector allocation - on a more aggregate level - can be found.

Table 4 provides a detailed comparison of source sectors split into categories for which a cross-comparison between the UK NAEI and EDGAR v4 could be sensibly conducted for $\mathrm{NO}_{\mathrm{x}}, \mathrm{NH}_{3}$ and $\mathrm{N}_{2} \mathrm{O}$. As some of the individual source sectors in NAEI and EDGAR do not fully match, the following discussion will focus on the subtotals for sector groups rather than on individual figures.

The figures for stationary combustion are quite similar overall, but $\mathrm{NO}_{\mathrm{x}}$ emissions in EDGAR v4 are 17\% lower, $\mathrm{N}_{2} \mathrm{O}$ from this source group is less than a third than those in the NAEI. For road transport, the picture is similar (17\% lower $\mathrm{NO}_{\mathrm{x}}$ emissions, $87 \%$ lower $\mathrm{N}_{2} \mathrm{O}$ emissions), while $\mathrm{NH}_{3}$ from road transport is $47 \%$ higher in EDGAR v4. $\mathrm{NO}_{\mathrm{x}}$ emissions from other mobile sources and machinery are about 32\% lower in EDGAR v4. These combustion sources, both stationary and mobile, are assumed to be best understood with low uncertainties typically attributed to $\mathrm{NO}_{\mathrm{x}}$ emission factors in general. Thus, the magnitude of 
differences in these sectors between NAEI and EDGAR v4, however, is larger than anticipated taking into account the uncertainty ranges assumed for the UK NAEI (see section 6.1).

On the other hand, total $\mathrm{NH}_{3}$ emissions from the sector manure management are quite similar $(\sim 6 \%$ lower in EDGAR v4), yet some significant differences between the emissions from individual animal types can be observed. EDGAR v4 has substantially higher emissions of $\mathrm{N}_{2} \mathrm{O}$ from manure management (about 6 times higher than NAEI), but less than one third of direct emissions from agricultural soils. This may hint at a difference in allocation between these subsectors. In addition to that, $\mathrm{NH}_{3}$ emissions directly originating from agricultural soils are 5.3 times higher in EDGAR v4.

Finally, NAEI lists a few sectors that are not subject to reporting obligations under EMEP, while EDGAR v4 - as an inventory primarily compiled for modelling purposes - does not make this distinction.

In summary, the difference between country total emissions between both inventories is within the uncertainty margins expected for $\mathrm{N}_{2} \mathrm{O}$ at $2.6 \%$ ( $\pm 15 \%$ uncertainty range for NAEI, see section 6.1), however larger for $\mathrm{NO}_{\mathrm{x}}$ emissions with EDGAR v4 being 20.9\% below NAEI, (NAEI assuming a $\pm 7 \%$ uncertainty range). $\mathrm{NH}_{3}$ emissions in EDGAR $\mathrm{v} 4$ are $36.9 \%$ higher than in the NAEI (uncertainty range for NAEI assumed to be $( \pm 20 \%)$. However, for all three substances, sectoral allocation are quite different between inventories, which has direct implications for the use of the emissions for atmospheric modelling, e.g. the temporal profiles and spatial distribution of emissions in different sectors. The current structure of the inventories such as NAEI and hence EMEP - which are compiled primarily for reporting and compliance monitoring purposes - is not always detailed enough for modellers to fully assess the quality of the inventory and supporting datasets are often not accessible or documented well enough.

\subsubsection{Observations for all regions}

The overview comparisons of sectoral emission shares in the US and the China (see Figs. 5 and 6) indicate some substantial differences between the emission profiles of the US (and similarly Europe) on one side and China on the other. In particular the high contribution of emissions from agriculture to total $\mathrm{NH}_{3}$ emissions in general is evident. In the case of $\mathrm{NO}_{\mathrm{x}}$ emissions, mobile sources (road transport and offroad) contribute a larger share in Europe and the US, while power generation based on fossil fuels (coal mainly) in the energy industries of China and the US contribute in a similar magnitude. A remarkable difference can be seen in the contribution of road transport to $\mathrm{N}_{2} \mathrm{O}$ emissions and - to a smaller extent $-\mathrm{NH}_{3}$ emissions in the US compared to Europe. The reason for the difference in transport $\mathrm{N}_{2} \mathrm{O}$ emissions can be explained by comparing EFs for running (hot)
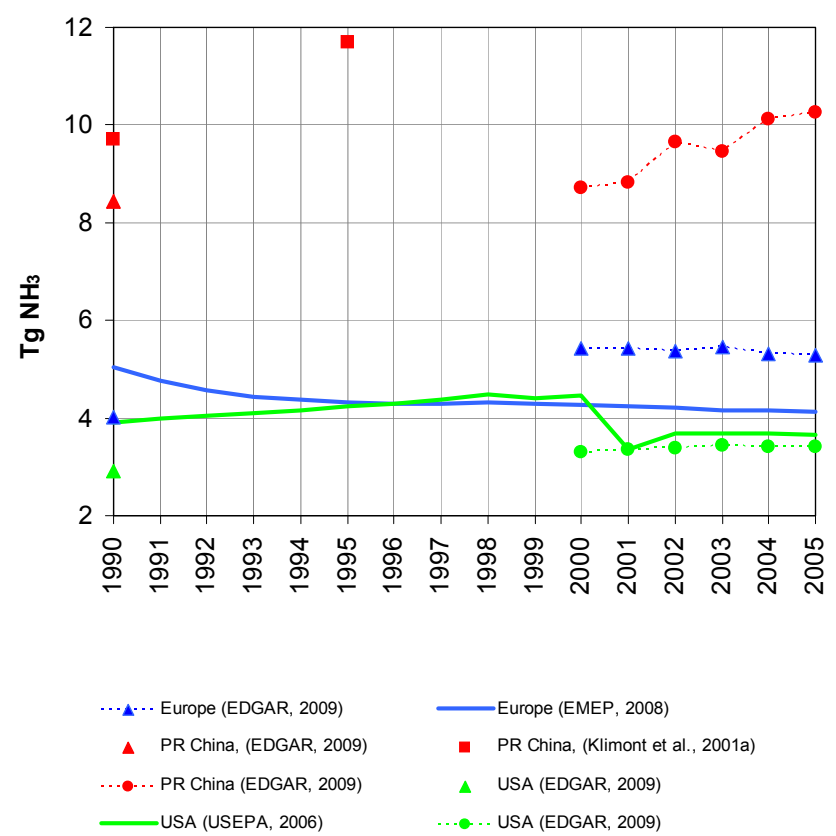

Fig. 8. Estimated trends in $\mathrm{NH}_{3}$ emissions in Europe, the US and the China for the period 1990-2005.

emissions for passenger cards advanced three-way catalytic converters) for US and European vehicles in the IPCC Emission Factor Database (EFDB, http://www.ipcc-nggip.iges.or. $\mathrm{jp} / \mathrm{EFDB} / \mathrm{main} . \mathrm{php})$. While the EF for US vehicles is given as $9 \mathrm{mg} / \mathrm{km}$, the EFs for European vehicles (based on the COPRT IV model, http://lat.eng.auth.gr/copert/) range from $0.7 \mathrm{mg} / \mathrm{km}$ (highway driving) to $2 \mathrm{mg} / \mathrm{km}$ (urban driving). It is not straightforward to assess, if all $\mathrm{N}_{2} \mathrm{O}$ emissions from road transport in the US and in Europe have been calculated using these factors, but the magnitude of difference suggests substantially different assumptions as to technology and resulting emission factors in both regions.

A comparison between the US NEI and EDGAR v4 indicates overall quite similar total figures, except for $\mathrm{N}_{2} \mathrm{O}$ (EDGAR v4 substantially higher than US NEI). However, the sectoral structure for $\mathrm{NO}_{\mathrm{x}}$ and $\mathrm{NH}_{3}$ shows remarkable difference, for instance regarding the split between manure management and agricultural soils $\left(\mathrm{NH}_{3}\right)$ and power generation $\left(\mathrm{NO}_{\mathrm{x}}\right)$.

\subsection{Emission trends and implications}

Apart from the analysis of emission inventories for specific years, which give a snapshot for a certain point in time, looking at the temporal trends in emissions can give valuable insight in the development of both emissions as well as the methodologies applied for their calculation.

The trend for $\mathrm{NH}_{3}$ emissions (Fig. 8) shows no significant reductions in the 15 year period indicated. A moderate downward trend can be observed in Europe $(-18 \%)$, which 
Table 4. Detailed comparison between source sectors in the UK National Atmospheric Emissions Inventory (NAEI, 2008) and EDGAR v4 (EDGAR, 2009) for the year 2005.

\begin{tabular}{|c|c|c|c|c|c|c|c|}
\hline \multirow[b]{2}{*}{ NFR code } & \multirow[b]{2}{*}{ NFR Name } & \multicolumn{3}{|c|}{ UK NAEI } & \multicolumn{3}{|c|}{ EDGAR v4 } \\
\hline & & $\mathrm{NO}_{\mathrm{x}}$ & $\mathrm{NH}_{3}$ & $\mathrm{~N}_{2} \mathrm{O}$ & $\mathrm{NO}_{\mathrm{x}}$ & $\mathrm{NH}_{3}$ & $\mathrm{~N}_{2} \mathrm{O}$ \\
\hline $1 \mathrm{~A} 1 \mathrm{a}$ & Public Electricity and Heat Production & 372.60 & 0.70 & 3.48 & 410.14 & 0.57 & 2.65 \\
\hline $1 \mathrm{~A} 1 \mathrm{~b}$ & Petroleum Refining & 30.70 & & 0.39 & 3.20 & & 0.01 \\
\hline $1 \mathrm{~A} 1 \mathrm{c}$ & Combustion in Manufacture of Solid Fuels and Other Energy Industries & 58.80 & & 1.28 & & & \\
\hline $1 \mathrm{~A} 2 \mathrm{a}$ & Combustion in Iron and Steel Manuf. Industry & 19.50 & & 0.33 & 12.19 & & \\
\hline \multirow[t]{2}{*}{$1 \mathrm{~A} 2 \mathrm{f}$} & Combustion in Other Manufacturing Industry & 232.80 & 0.40 & 4.00 & 165.73 & 0.17 & 0.36 \\
\hline & Subtotal stationary combustion & 714.40 & 1.10 & 9.48 & 591.26 & 0.75 & 3.02 \\
\hline 1A3aii(i) & Civil Aviation - Domestic Take-Off and Landing & 1.80 & & 0.02 & & & \\
\hline \multirow[t]{2}{*}{ 1A3aii(ii) } & Civil Aviation - Domestic Cruise & 7.10 & & 0.05 & & & \\
\hline & Subtotal aviation & 8.80 & & 0.07 & & & \\
\hline $1 \mathrm{~A} 3 \mathrm{bi}$ & Road Transport - Passenger Cars & 215.10 & 9.20 & 14.13 & 457.04 & 13.98 & 2.14 \\
\hline 1A3bii & Road Transport - Light Duty Vehicles & 58.50 & 0.20 & 1.19 & & & \\
\hline 1A3biii & Road Transport - Heavy Duty Vehicles & 274.00 & 0.10 & 1.09 & & & \\
\hline \multirow[t]{2}{*}{ 1A3biv } & Road Transport - Mopeds \& Motorcycles & 1.30 & & 0.01 & & & \\
\hline & Subtotal road transport & 548.90 & 9.50 & 16.42 & 457.04 & 13.98 & 2.14 \\
\hline $1 \mathrm{~A} 3 \mathrm{c}$ & Railways - Mobile Sources & 36.90 & & 0.80 & & & \\
\hline 1A3dii & National Navigation (including Inland Waterways and Maritime Activities) & 92.10 & & 0.10 & & & \\
\hline \multirow[t]{2}{*}{ 1A3eii } & Other Off-Road Mobile Sources and Machinery & 5.60 & & 0.19 & 91.06 & 0.03 & 0.05 \\
\hline & Subtotal other mobile sources & 134.60 & & 1.09 & 91.06 & 0.03 & 0.05 \\
\hline $1 \mathrm{~A} 4 \mathrm{a}$ & Commercial/Institutional Combustion Plants & 20.90 & & 0.08 & 110.14 & 0.77 & 0.51 \\
\hline \multirow[t]{2}{*}{ 1A4bi } & Residential Combustion Plants & 108.30 & 1.50 & 0.37 & & & \\
\hline & Subtotal residential/commercial combustion & 129.20 & 1.50 & 0.45 & 110.14 & 0.77 & 0.51 \\
\hline 1A4bii & Household and Gardening (Mobile Machinery) & 0.90 & & 0.02 & & & \\
\hline $1 \mathrm{~A} 4 \mathrm{ci}$ & Stationary Combustion Plants (Agriculture/Forestry/Fishing) & 0.70 & & 0.01 & & & \\
\hline $1 \mathrm{~A} 4 \mathrm{cii}$ & Agricultural/Forestry Off-Road Vehicles and Other & 52.10 & & 1.59 & & & \\
\hline $1 \mathrm{~A} 5 \mathrm{~b}$ & Other Mobile Sources (including Military) & 22.20 & & 0.08 & & & \\
\hline $1 \mathrm{~B} 1 \mathrm{~b}$ & Fugitive Emissions from Fuels - Solid Fuels/Transformation & 0.20 & 0.10 & 0.00 & & & \\
\hline 1B2ai & Fugitive Emissions from Fuels, Oil - Exploration, Production, Transport & 0.70 & 0.10 & 0.00 & & & \\
\hline $1 \mathrm{~B} 2 \mathrm{c}$ & Oil and Natural Gas/Venting and Flaring & 2.20 & & 0.14 & & & \\
\hline $2 \mathrm{~A} 7$ & Other Production & & 0.50 & & & & \\
\hline 2B2 & Nitric Acid Production & 0.60 & & 6.52 & & & \\
\hline $2 \mathrm{~B} 3$ & Adipic Acid Production & & & 2.50 & & & \\
\hline 2B5 & Other Chemical Industry Processes & 0.40 & 4.00 & & & 0.67 & 66.14 \\
\hline $2 \mathrm{C}$ & Metal Production & 1.60 & & 0.03 & & & \\
\hline 2D1 & Pulp and Paper Production & & & & & & \\
\hline 2D2 & Food and Drink Production & & 0.90 & & & & \\
\hline \multirow[t]{2}{*}{$3 \mathrm{D}$} & Other Solvent Use (including products containing HMs and POPs) & & 1.20 & & & & \\
\hline & Subtotal miscellaneous sources & 157.50 & 6.80 & 12.59 & & 0.67 & 66.14 \\
\hline $4 \mathrm{~B} 12$ & Solid Storage and Drylot & & & 0.15 & & & \\
\hline $4 \mathrm{~B} 13$ & Manure Management - Other & & 17.90 & 3.80 & & & \\
\hline $4 \mathrm{~B} 1 \mathrm{a}$ & Manure Management - Dairy & & 86.00 & & & 52.20 & 5.72 \\
\hline $4 \mathrm{~B} 1 \mathrm{~b}$ & Manure Management - Non-Dairy & & 63.60 & & & 75.92 & 8.10 \\
\hline $4 \mathrm{~B} 3$ & Manure Management - Sheep & & 12.10 & & & 23.49 & 7.33 \\
\hline 4B6 & Manure Management - Horses & & 4.40 & & & 0.49 & 0.08 \\
\hline 4B 8 & Manure Management - Swine & & 26.70 & & & 17.85 & 0.53 \\
\hline \multirow[t]{2}{*}{$4 \mathrm{~B} 9$} & Manure Management - Poultry & & 37.70 & & & 63.70 & 0.29 \\
\hline & Subtotal manure management & & 248.40 & 3.80 & & 233.65 & 22.04 \\
\hline 4D1 & Direct Emissions from Agricultural Soils & & 35.60 & 81.31 & 29.34 & 190.81 & 26.07 \\
\hline $4 \mathrm{~F}$ & Field Burning of Agricultural Wastes & & 1.90 & & 2.69 & 0.92 & 0.05 \\
\hline $4 \mathrm{G}$ & Other Agricultural (including use of pesticides) & & & 0.19 & & & \\
\hline \multirow[t]{2}{*}{$5 \mathrm{~B}$} & Forest and Grassland Conversion & 0.20 & & 0.01 & & & \\
\hline & Subtotal agricultural soils and wastes & 0.20 & 1.90 & 0.20 & 2.69 & 0.92 & 0.05 \\
\hline $6 \mathrm{~A}$ & Solid Waste Disposal on Land & & 4.10 & & & & \\
\hline $6 \mathrm{~B}$ & Waste Water Handling & & 5.50 & 3.92 & & & 5.03 \\
\hline $6 \mathrm{C}$ & Waste Incineration & 1.70 & & 0.16 & & & 0.21 \\
\hline \multirow[t]{2}{*}{$6 \mathrm{D}$} & Other Waste (incl. Composting and Biogas Prod.) & 0.30 & & & & 0.50 & 0.62 \\
\hline & Subtotal waste handling & 2.00 & 9.60 & 4.08 & & 0.50 & 5.87 \\
\hline 7 & Other & & 0.30 & & & & \\
\hline $\mathrm{z}_{5} 5 \mathrm{E}$ & Other Sources and Sinks & & 8.30 & & & & \\
\hline z_1A3ai(i) & International Aviation -Take-Off and Landing & & & 0.08 & & & \\
\hline z_1A3ai(ii) & International Aviation - Cruise & & & 1.04 & & & \\
\hline$z_{-} 1 \mathrm{~A} 3 \operatorname{di}(\mathrm{i})$ & International Maritime and Inland Waterway Navigation & & & 0.15 & & & \\
\hline & Total & 1619.8 & 323.00 & 129.2 & $\begin{array}{l}1281.5 \\
-20.9 \%\end{array}$ & $\begin{array}{l}442.1 \\
+36.9 \%\end{array}$ & $\begin{array}{l}125.9 \\
-2.6 \%\end{array}$ \\
\hline
\end{tabular}




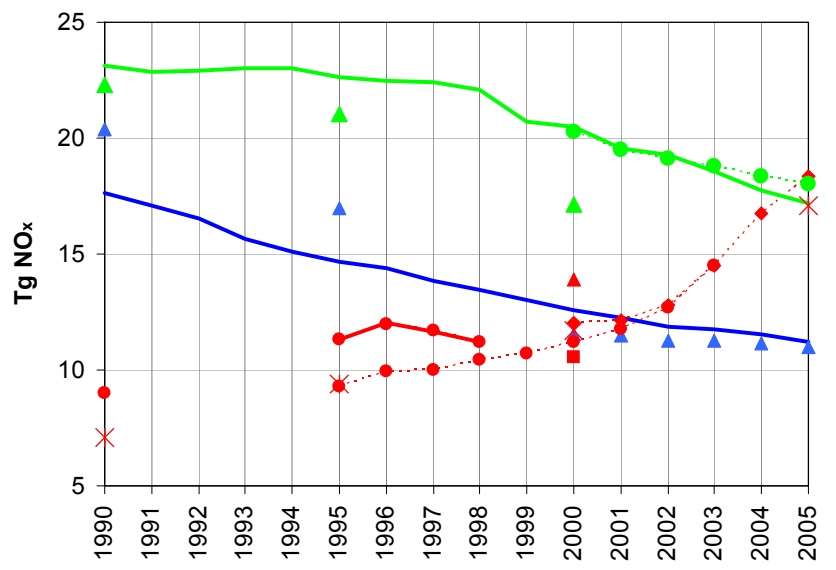

A Europe (EDGAR, 2009)

- PR China (EDGAR, 2009)

..... PR China (Tian et al., 2001)

-. PR China (EDGAR, 2009)

* PR China (IIASA, 2009)

USA (USEPA, 2006)

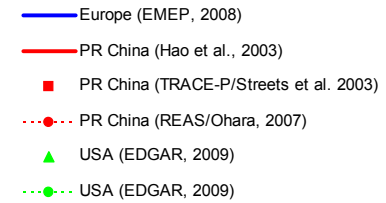

Fig. 9. Estimated trends in $\mathrm{NO}_{\mathrm{x}}$ emissions in Europe, the US and the China for the period 1990-2005.

is largely attributable to the political restructuring of Eastern Europe after 1989 (Horvath and Sutton, 1998) while US emissions have increased slightly in the period from 1990 to 2000. Although the values shown in Fig. 8 indicate a small (6\%) reduction below 1990 for 2005 , this is due to a change in the calculation methodology in 2000, which was has not been reapplied to the earlier years.

If the old methodology had been maintained throughout (with 2001 set equal to 2000), this would imply an overall national increase of about 22\% between 1990 and 2005 comparing the US NEI values for both years. Chinese emissions of $\mathrm{NH}_{3}$ have as of yet only been estimated by few authors, with 1990 emission estimates ranging between 8 and $10 \mathrm{Tg}$, with a figure of $11.7 \mathrm{Tg}$ (Klimont, 2001b) for the year 1995 . This latter figure would indicate an increase of $21 \%$ within these five years. This figure is attributed by Klimont (2001b) to a estimated $27 \%$ increase in $\mathrm{NH}_{3}$ emissions from livestock and a $19 \%$ increase in fertilizer related emissions, reflecting increased consumption of livestock products in China, especially poultry (57\% increase). Figure 9 displays trends in $\mathrm{NO}_{\mathrm{x}}$ emissions for the same period based on data from EMEP, EDGAR and the USEPA NEI In addition to that, a number of figures from the literature for specific years or periods have been used as well as data from the GAINS model (IIASA, 2009) to discuss the trend in China. A general downward trend can be observed for Europe and the US, reflecting significant emission control activities in particular with regard to stationary and mobile combustion sources. This trend occurs both in the official inventory figures (EMEP, USEPA) and the EDGAR data, with similar slopes, but with different starting points.

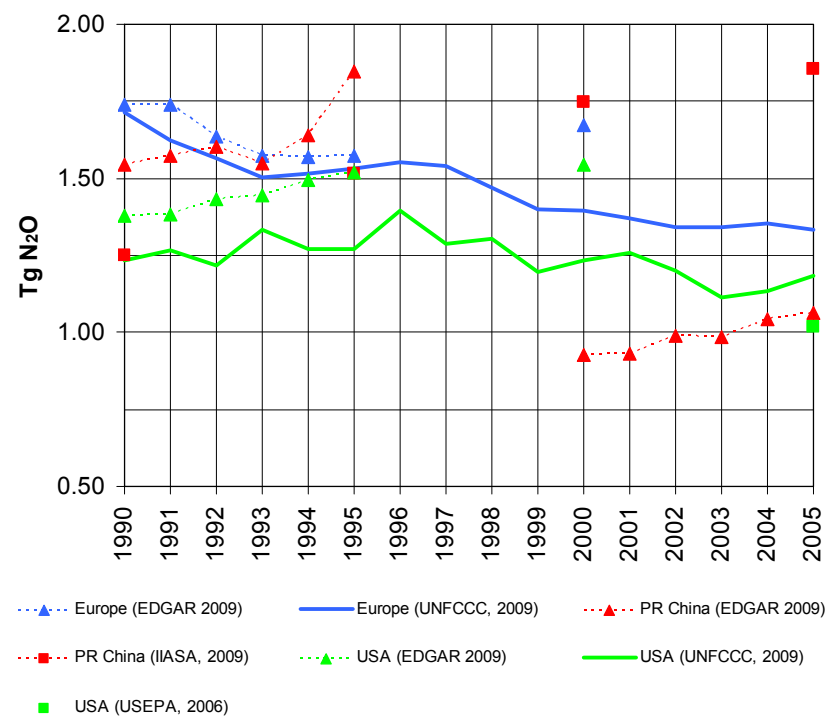

Fig. 10. Estimated trends in $\mathrm{N}_{2} \mathrm{O}$ emissions in Europe, the US and the China for the period 1990-2005. The observed break in trend for EDGAR 2009 arises from differences between EDGAR v4 (2000 onwards) and EDGAR 32/EDGAR Hyde 1.3/1.4 for (1990-1995). While there is a consistent upward trend, some natural sources previously included in the analysis have not been included in EDGAR v4; For further detail, see (EDGAR, 2009) for all EDGAR inventory datasets.

In the case of the China, no official dataset for a longer term trend analysis is yet available. Using a synthesis of satellite observations and bottom-up emission inventory development, Zhang et al. (2007) for instance conclude that $\mathrm{NO}_{\mathrm{x}}$ emissions in China from 1995-2004 likely increased by $70 \%$. Those studies (Tian et al., 2001; Hao et al., 2003; Streets et al., 2003; Ohara et al., 2007) displayed in Fig. 9 show reasonable agreement for individual years, with a spread of approx. $3 \mathrm{Tg}$ for the year 2000. With a starting point around 7-8 $\mathrm{Tg} \mathrm{NO}_{\mathrm{x}}$ in 1990 and estimated values around $17-18 \mathrm{Tg}$ in 2005, a further substantial increase of China's $\mathrm{NO}_{\mathrm{x}}$ emissions has to be anticipated, which may well off-set the reductions in Europe and the US.

Emission trends for $\mathrm{N}_{2} \mathrm{O}$ emissions are subject to significant uncertainties in the same way as the annual emission estimates. UNFCCC reported data for Europe and the US, as well as emission figures from the EDGAR Hyde 1.4 (Van Aardenne et al., 2001) inventory of historic emission trends and EDGAR v4 (EDGAR, 2009) emissions for the year 2000, which also include China make a rough trend assessment possible (Fig. 10.). For Europe, a consistent downward trend for both EDGAR Hyde 1.4 and UNFCCC figures can be observed, but it has to be noted that EDGAR FT32 (Olivier et al., 2005; Van Aardenne et al., 2005) for the year 2000 are significantly above UNFCCC figures, and higher than 1995 emissions from EDGAR Hyde 1.4. (EDGAR, 2009). 
For the US, EDGAR Hyde 1.4 indicates a slow increase for the period 1990 to 1995 , with 2000 emissions remaining at approximately the same level, while UNFCCC figures remains around $1.25 \mathrm{Tg} \mathrm{N}_{2} \mathrm{O} \mathrm{yr}^{-1}$ until 2000, then shows a slight downward move with an increase again towards 2005. A significant increase of $\mathrm{N}_{2} \mathrm{O}$ emissions from the China is portrayed in EDGAR Hyde 1.4, but EDGAR FT32 emissions for 2000 are lower than EDGAR Hyde for 1995, and not in the pathway that could be interpolated from the sharp increase of Chinese emissions in the period 1990 to 1995. The GAINS model (IIASA, 2009) contains five-yearly figures for $\mathrm{N}_{2} \mathrm{O}$, which support the general upward trend, however less steep than by EDGAR Hyde 1.4, with the GAINS value for 2005 being similar to the HYDE 1.5 for 1995 at about $1.8 \mathrm{Tg} \mathrm{N}_{2} \mathrm{O}$. Due to the small amount of studies available to elicit a trend and significant uncertainties associated to the quantification of $\mathrm{N}_{2} \mathrm{O}$ emissions in general, some caution is needed in interpolating beyond 2005 based on the trends observed for the period 1990 to 2005.

\section{Discussion and conclusions}

\subsection{Completeness and coverage of emission inventories}

The picture presented in the previous sections is quite diverse across different dimensions. In many cases, emission inventories clearly reflect the purpose they have been designed for, i.e. serving for regulatory purposes (e.g. the UNFCCC and UNECE CLRTAP EMEP inventories), where compliance with international protocols drives the need for a pragmatic accounting system for emissions. On the other hand, inventories such as the EDGAR emission database are bottom-up, science driven compilations of emissions based on emission factors and - typically - publicly available, statistical information on activity rates, emission factors and suchlike. While the legal implications and validation of national submissions are key aspects for the former, the latter have the main objective to provide comprehensive and consistent datasets for (atmospheric) modelling exercises in a timely manner. This is somewhat reflected as well in the sectoral structure in which these inventories are compiled.

In terms of completeness, two aspects need to be considered: firstly, are all known sources of emissions reflected in the inventory, or can missing sources be identified based on the state-of-the-art of scientific research? And secondly, have all known emissions been calculated based on a consistent methodology and no figures are missing or not estimated?

Officially reported emission inventory data are often incomplete with regard to both aspects, respectively are only available with a certain time lag due to the time it takes to compile them based on official statistics and to undergo validation and error checking, before they are officially submitted. Their legal implications for monitoring compliance with international treaties or protocols, however, and the result- ing reviews both within the country and by external review processes provides a crucial stage of quality control. Independent inventory compilers on the other hand do not always have access to the latest, most accurate and most detailed country specific EFs, activity rates, penetration of measures and technology etc. for each country and hence are prone to over/underestimate emissions from individual sectors. Yet, by providing consistent (as regarding methodology used), comprehensive (no gaps, spatial coverage and sectoral resolution) and complete (anthropogenic and natural sources, species) datasets for recent years, they provide vital input for modelling studies. There is, undoubtedly, a clear need for validation for both and here inventory compilers and atmospheric modellers need to work in close collaboration to mutually improve model results.

For all inventories, there have clearly been sources missing that have been identified and quantified in recent years, for instance emissions from $\mathrm{NO}$ from agricultural and forest soils and other natural and biogenic emissions $\left(\mathrm{NH}_{3}\right.$ from sea birds, $\mathrm{NO}_{\mathrm{x}}$ from lightning and forest fires etc.). As most of the inventories compiled for regulatory purposes focus on anthropogenic (i.e. regulated and controllable) sources, they often do not calculate and report natural and biogenic emissions.

Compared to the main contributing sectors of anthropogenic emissions, the contributions of these missing sources to date may be small, but with decreasing emissions due to emission control activities, their relative importance will continue to grow in the future. However, there may yet be major missing sources in the inventories. For example low temperature coal and other biomass combustion (Sutton et al., 2008) may be a major additional source of ammonia emissions in China that has yet to be quantified. Although of historical importance (Fowler et al., 2004), coal burning in residential combustion sources is no longer a significant activity for much of Europe and North America. Similarly, there remain major uncertainties in regional nitrous oxide emissions, as indicated by the assessment of Crutzen et al. (2008) who estimated from the global rate of $\mathrm{N}_{2} \mathrm{O}$ increase that total agricultural emissions should be $4-5 \%$ of the input reactive nitrogen, which is larger than the base emission rate of $1 \%$ used in the IPCC methodology. This differential is most likely due to other biogenic sources of $\mathrm{N}_{2} \mathrm{O}$, but it cannot be ruled out that there are missing industrial or combustion source emissions.

In comparing the regulatory and science based inventories, it is possible to identify systematic errors or gaps in both, provided there is sufficient level of detail available with regard to the sectoral disaggregation, emission factors, control technologies and activity rates, allowing for an in-depth assessment of the methodology used and factors and values applied. Documents such as IPCC (2000) providing Good Practice Guidance and Uncertainty Management in National Greenhouse Gas Inventories can be essential to systematically check for completeness of inventories, missing sources 
and general methodology to assess and quantify uncertainties.

The coverage of regions and substances for instance in the EDGAR inventory is comprehensive, but the fact that the $\mathrm{NH}_{3}$ inventory for the time after 1990 has not been compiled for a long time hints at the substantial resources and time required to compile these datasets. This is particularly problematic in the case of ammonia, as this is going to be a key pollutant to be targeted in future reduction efforts at least in Europe due to its growing relative importance for the control of secondary aerosol concentrations and its contribution to acidification and eutrophication.

Finally, the spatial and temporal coverage of emission data as input to atmospheric dispersion models is a key issue. On a global scale, a resolution of $1^{\circ} \times 1^{\circ}$ or $0.5^{\circ} \times 0.5^{\circ}$ is sufficient to capture the general trends and concentrations/depositions. Yet, for regional and local modelling, inventories with a resolution of more than $10 \mathrm{~km} \times 10 \mathrm{~km}$ are likely to miss vital distribution patterns and thus lead to mismatches between model results and observations. The EMEP modelling team has recently begun testing $25 \mathrm{~km} \times 25 \mathrm{~km}$ and $10 \mathrm{~km} \times 10 \mathrm{~km}$ resolutions for the EMEP domain, which will - if established - have implications for the required input data resolution of the EMEP inventory in the long run (see http://www.emep.int/publ/reports/2008/status_report_1_ 2008.pdf). And while national emission inventories with a spatial resolution of e.g. $1 \mathrm{~km} \times 1 \mathrm{~km}$ are available for some countries, they will rarely have been compiled using the same datasets and assumptions as the global inventories, hence may create boundary problems when nesting different inventories for modelling purposes (see as well Reis et al., 2008). The differences in the sectoral emissions splits between the inventories described previously have implications as well for the temporal and spatial profiles of these emissions when used as input for atmospheric dispersion models. Ultimately, this may lead to quite different ambient modelled concentrations of primary and secondary pollutants depending on which inventory data are used, in particular for pollutants such as tropospheric ozone, where the time and the location of the precursor emissions matters.

\subsection{Trend analysis}

The trends for the three gases investigated in this paper show quite different patterns, as well as differences between the countries and regions included in this paper. $\mathrm{NO}_{\mathrm{x}}$ emissions in Europe and the US have fallen markedly, reflecting successful emission control policies especially since the early 1990s (see e.g. Vestreng et al., 2008). $\mathrm{NO}_{\mathrm{x}}$ emissions from the China, while much lower than those of Europe and the US, do not show a consistent trend due to the lack of data available. However, with the substantial growth of the Chinese economy and hence energy demand, which is mainly supplied by coal fired power plants, a continuing increase of $\mathrm{NO}_{\mathrm{x}}$ emissions can be anticipated.
Ammonia emission trends show a quite different picture, with only minor reductions in Europe over the period of 1990 to 2005 , which were mainly a side effect of political restructuring around 1990, while the US ammonia emissions have increased by around $20 \%$ over the period. In both areas there have been major within-region differences. For example, in Europe, significant ammonia emission reductions were estimated or Denmark and the Netherlands, where control policies have been in place for more than a decade, while conversely emissions in Spain are estimated to have increased substantially over the last 20 years. In Europe there has been substantial debate as to whether estimated emission trends are verified by measurements (e.g. Horvath and Sutton, 1998; Sutton et al., 2003), and a recent assessment by Bleeker et al. (2009) concluded that the trend in reductions in ammonia emission in the Netherlands is supported by the measurements, though debate remains concerning the absolute magnitude of emissions. For the US, the overall increase in ammonia emissions is matched by major regional increases, especially in the Midwest (Sutton et al., 2008, based on Lehman et al., 2007) and in the Eastern US (Bleeker et al., 2009). With only a few data points available for China, it is yet evident that emissions are estimated to be about two to three times higher than European or US emissions in this period. In addition to that, Klimont (2001) projected a steep increase in $\mathrm{NH}_{3}$ emissions for the period 1990-1995, equally matched between increased livestock numbers and mineral fertilizer use. Future projections for China suggest further increase, with Klimont (2001) estimating emissions in the range $8.2 \mathrm{Tg} \mathrm{NH}_{3}$ to $19.9 \mathrm{Tg} \mathrm{NH}_{3}$ for 2030 .

Trends for nitrous oxide emissions finally indicate a slow decrease of emissions in Europe, a slight increase in US $\mathrm{N}_{2} \mathrm{O}$ emissions, and a substantial growth in emissions in China. However, the trends depicted by data from the EDGAR Hyde 1.4 project and those reported to UNFCCC do not match well with 2000 figures from EDGAR FT32, indicating different methodologies, respectively potentially different source sectors being included/excluded.

Some of the differences hint as well at the varying state of knowledge and certainty with regard to both the current amount and the future direction of emissions and trends. For European and US emissions, $\mathrm{NO}_{\mathrm{x}}$ emission values can be seen as quite robust and well understood, while in particular the trend of $\mathrm{NO}_{\mathrm{x}}$ emissions from China is highly uncertain due to the unknown developments in the Chinese energy demand and potential efficiency gains and decoupling efforts between economic growth and energy demand. This is to some extent also the case for European $\mathrm{NO}_{\mathrm{x}}$ emissions. The phasing out of nuclear power on the one hand, and the plans to increase the use of domestic coal and biomass for power generation on the other hand make it more difficult to predict the development of $\mathrm{NO}_{\mathrm{x}}$ emissions from the power generation sector beyond 2010 (EMEP, 2009).

Ammonia emissions are dominated by agricultural production, and here future trends will be heavily influenced by 
agricultural policies, such as for instance the Common Agricultural Policy (CAP) Reform in Europe. Livestock numbers and the implementation of measures under the Integrated Pollution Prevention and Control (IPPC) directives will introduce further stringent measures to reduce $\mathrm{NH}_{3}$ emissions from animal housing. More evidence is yet required to assess if China's ammonia emissions are indeed growing at a rate as the few data points suggest, for example illustrated in the wide range between the 2030 projections of Klimont (2001), the high estimate of which reflected a simple projection of activity statistics, while the low projection assumed full implementation of Best Available Techniques.

For $\mathrm{N}_{2} \mathrm{O}$, both the general uncertainty about the emissions, and their trends, are significantly larger than for the other pollutants. How trends after 2010 evolve will depend on future negotiations and the way how Kyoto and post-Kyoto greenhouse gas emission targets are achieved and how further reductions will be set.

\subsection{Future research needs}

A first step to reduce the uncertainties identified above and to support the efforts to close the gaps in $\mathrm{N}$ budgets on a global or regional scale will be to detect missing sources and to quantify their contribution to overall emissions. This is of particular importance in the field of natural and semi-natural sources of emissions, which are often not yet well covered by emission inventories, which focus on anthropogenic emissions due to their history and heritage. Current research targeting unknown emission sources on the one hand, and recent achievements in quantifying emissions e.g. of NO from agricultural and forest soils (Skiba et al., 2001: Friedrich, 2009), $\mathrm{NH}_{3}$ from seabirds and other animals (Blackall et al., 2007) may become vital in the future with anthropogenic emissions declining, yet are often not suited for reporting in (static) inventories due to their dependence on meteorological factors. In this context, the inventory compilers and modelling communities need to work in close collaboration to avoid some of these sources being missed or inconsistently treated. At the same time further efforts are needed to better quantify important but highly uncertain emissions such as ammonia from combustion sources (Fowler et al., 2004; Sutton et al., 2008) and apparently missing sources of nitrous oxide (Crutzen et al., 2008). Only if inventories reflect the current state-of-the-art of research can validation and verification experiments, comparing model calculations with observations on different spatial scales (e.g. Bleeker et al., 2009; Bergamaschi et al. 2005; Henze et al., 2008) deliver meaningful results towards a better understanding of the processes through which reactive and non-reactive nitrogen species contribute to air pollution and climate change. In addition, a fully quantified nitrogen cycle is a key requirement for the design of intelligent and effective management options towards reducing the negative impacts of $\mathrm{N}$ along the full nitrogen cascade. Complete and accurate emission in- ventories of all nitrogen species are a crucial building block for this.

Acknowledgements. Most of the work described here has been supported by a range of research projects and ongoing activities, such as the European Commission funded research project NitroEurope IP, COST Action 729 the ESF Programme Nitrogen in Europe (NinE). The present paper is a contribution to activities under the International Nitrogen Initiative (INI) and the National Basic Research Program of China (Grant No. 2007CB407303). The US EPA through its Office of Research and Development (partially funded and collaborated in) the research described here. It has been subjected to Agency review and approved for publication. The authors would further express their gratitude to the EDGAR team at the Joint Research Centre of the European Commission in Ispra for providing EDGAR v4 datasets for the analysis.

Edited by: J. G. Murphy

\section{References}

Akimoto, H. and Narita, H.: Distribution of $\mathrm{SO}_{2}, \mathrm{NO}_{\mathrm{x}}$ and $\mathrm{CO}_{2}$ emission from fuel combustion and industrial activities in Asia with $1^{\circ} \times 1^{\circ}$ resolution, Atmos. Environ., 28, 213-225, 1994 .

Bai, N. B.: The emission inventory of $\mathrm{SO}_{2}, \mathrm{NO}_{\mathrm{x}}$ and $\mathrm{CO}_{2}$ in China. The Atmospheric Ozone Variation and Its Effect on the Climate and Environment in China, China Meteorological Press, 145150, 1996.

Bergamaschi, P., Krol, M., Dentener, F., Vermeulen, A., Meinhardt, F., Graul, R., Ramonet, M., Peters, W., and Dlugokencky, E. J.: Inverse modelling of national and European $\mathrm{CH}_{4}$ emissions using the atmospheric zoom model TM5, Atmos. Chem. Phys., 5, 2431-2460, 2005

Bishop, G. A., and Stedman, D. H.: A Decade of On-road Emission Measurements, Environ. Sci. Technol., 42, 1651-1656, 2008.

Blackall, T. D., Wilson, L. J., Theobald, M. R., Milford, C., Nemitz, E., Bull, J., Bacon, P. J., Hamer, K. C., Wanless, S., and Sutton, M. A.: Ammonia emissions from seabird colonies, Geophys. Res. Lett., 34, L10801, doi:10.1029/2006GL028928, 2007.

Bleeker, A., Sutton, M. A., Acherman, B., Alebic-Juretic, A., Aneja, V. P., Ellermann, T., Erisman, J. W., Fowler, D., Fagerli, H., Gauger, T., Harlen, K. S., Hole, L. R., Horváth, L., Mitosinkova, M., Smith, R. I., Tang, Y. S., and van Pul., A.: Linking ammonia emission trends to measured concentrations and deposition of reduced nitrogen at different scales, in: Atmospheric Ammonia: Detecting emission changes and environmental impacts, edited by: Sutton, M. A., S. R. a. S. B., Springer, New York, USA, 123-180, 2009.

Bouwman, A. F., Lee, D. S., Asman, W. A. H., Dentener, F. J., Van der Hoek, K. W., and Olivier, J. G. J.: A global high-resolution emission inventory for ammonia, Global Biogeochem. Cy., 11, 561-587, 1997.

Bradshaw, J., Davis, D., Grodzinsky, G., Smyth, S., Newell, R., Sandholm, S., and Liu, S.: Observed distribution of nitrogen oxides in the remote free troposphere from the NASA global tropospheric experiment programs, Rev. Geophys., 38, 111-116, 2000 . 
Brasseur, G. P., Orlando, J. J., and Tyndall, G. S.: Atmospheric Chemistry and Global Change, Oxford University Press, New York, USA, 1999.

Crutzen, P. J., Mosier, A. R., Smith, K. A., and Winiwarter, W.: $\mathrm{N}_{2} \mathrm{O}$ release from agro-biofuel production negates global warming reduction by replacing fossil fuels, Atmos. Chem. Phys., 8, 389-395, 2008, http://www.atmos-chem-phys.net/8/389/2008/.

Del Grosso, S. J., Parton, W. J., Mosier, A. R., Hartman, M. D., Brenner, J., Ojima, D. S., Schimel, D. S.: Simulated Interaction of Carbon Dynamics and Nitrogen Trace Gas Fluxes Using the DAYCENT Model, in: Modeling Carbon and Nitrogen Dynamics for Soil Management edited by: Schaffer, M., Ma, L., and Hansen, S., CRC Press. Boca Raton, FL, USA, 303-332. 2001.

Dragosits, U., Dore, A., Sheppard, L., Vieno, M., Tang, Y. S., Theobald, M., and Sutton, M.: Sources, dispersion and fate of atmospheric ammonia. edited by: Hatfield, J. L., Follett, R. F., Nitrogen in the Environment - Sources, Problems, and Management, Academic Press, 333-393, 61 pp., 2008

EDGAR: Emissions Database for Global Atmospheric Research (EDGAR): http://edgar.jrc.ec.europa.eu/, EDGAR v4, EDGAR FT32, EDGAR Hyde datasets, last access: 20 August 2009, 2009.

EMEP Webdab emission data hosted by the Centre on Emission Inventories and Projections (CEIP): http://www.ceip.at/, last access: 20 August 2009, 2009.

Erisman, J. W., Mosquera, J., and Hensen, A.: Two options to explain the ammonia gap in The Netherlands, Environmental Science \& Policy, 4(2-3), 97-105, 2001.

Erisman, J. W.: The Nanjing Declaration on Management of Reactive Nitrogen, BioScience, 54, 286-287, 2004.

Erisman, J. W., Spranger, T., Sutton, M. A., Akselsson, C., AminHanjani, S., Anderson, H. V., ApSimon, H., Fagerli, H., Harmens, H., Havlikova, M., Hettelingh, J. P., Hcks, K., Horvath, L., Hutchings, N. J., Maasikimets, M., Maione, M., Reis, S., and Stenby, C.: Working Group 5: Nitrogen - integrated environmental policies. Proceedings of the UNECE/EC Saltsjobaden 3 Workshop, 2007.

Erisman, J. W., Sutton, M. A., Galloway, J. N., Klimont, Z., and Winiwarter, W.: 100 years of ammonia synthesis: how a single patent changed the world, Nature Geosci., 1, 636-639, 2008.

Fowler, D., O'Donoghue, M., Muller, J. B. A., Smith, R. I., Dragosits, U., Skiba, U., Sutton, M. A., and Brimblecombe, P.: A Chronology of Nitrogen Deposition in the UK between 1900 and 2000, Water, Air and Soil Pollution: Focus, 4, 9-23, 2004.

Friedrich, R.: Natural and biogenic emissions of environmentally relevant atmospheric trace constituents in Europe, Atmos. Environ., 43(7), 1377-1379, 2008.

Galloway, J. N.: The global nitrogen cycle: changes and consequences, Environ. Poll., 102, 15-24, 1998.

Galloway, J. N., Aber, J. D., Erisman, J. W., Seitzinger, S. P., W., H. R., Cowling, E. B., and Cosby, B. J.: The nitrogen cascade, BioScience, 53, 341-356, 2003.

Galloway, J. N., Dentener, F. J., Capone, D. G., Boyer, E. W., Howarth, R. W., Seitzinger, S. P., Asner, G. P., Cleveland, C. C., Green, P. A., Holland, E. A., Karl, D. M., Michaels, A. F., Porter, J. H., Townsend, A. R., and Vorosmarty, C. J.: Nitrogen cycles: past, present and future, Biogeochemistry, 70, 153-226, 2004.

Galloway, J. N., Townsend, A. R., Erisman, J. W., Bekunda, M.,
Cai, Z., Freney, J. R., Martinelli, L. A., Seitzinger, S. P., and Sutton, M. A.: Transformation of the Nitrogen Cycle: Recent Trends, Questions and Potential Solutions, Science, 320, 889892, 2008.

Gilliland, A. B., Appel, K. W., Pinder, R. W., and Dennis, R. L.: Seasonal $\mathrm{NH}_{3}$ Emissions for the Continental United States: Inverse Model Estimation and Evaluation, Atmos. Environ., 40, 4986-4998, 2006.

Godowitch, J. M., Hogrefe, C., and Rao, S. T.: Diagnostic Analyses of a Regional Air Quality Model: Changes in Modeled Processes Affecting Ozone and Chemical-Transport Indicators from $\mathrm{NO}_{\mathrm{x}}$ Point Source Emission Reductions, J. Geophys. Res., 113, D19303, doi:10.1029/2007JD009537, 2008.

Goebes, M. D., Strader, R., and Davidson, C.: An ammonia emission inventory for fertilizer application in the United States, Atmos. Environ., 37, 2539-2550, 2003.

Hao, J., Tian, H., and Lu, Y.: Emission inventories of $\mathrm{NO}_{\mathrm{x}}$ from commercial energy consumption in China, 1995-1998, Environ. Sci. Technol., 36, 552-560, 2002.

Henze, D. K., Seinfeld, J. H., and Shindell, D. T.: Inverse modeling and mapping US air quality influences of inorganic PM2.5 precursor emissions using the adjoint of GEOS-Chem, Atmos. Chem. Phys., Discuss., 8, 15031-15099, 2008.

Hettelingh, J. P., Posch, M., and Slootweg, J. (eds.): CCE Status Report 2008, Coordination Centre for Effects (CCE), 2008.

Horváth, L. and Sutton, M. A.: Long term record of ammonia and ammonium concentrations at K-puszta, Hungary, Atmos. Environ., 32, 339-344, 1998.

IIASA, The online version of the GAINS Model, http://gains.iiasa. ac.at/index.php/home-page, last access: 20 August 2009, 2009.

IPCC: Guidelines for National Greenhouse Gas Inventories: Greenhouse Gas Inventory Reference Manual (Revised 1996), IPCC/OECD/IGES, Bracknell, UK, 1997.

IPCC: Good Practice Guidance, Uncertainty Management in National Greenhouse Gas Inventorie, IPCC/IGES, Kanagawa, Japan, 2000, http://www.ipcc-nggip.iges.or.jp/public/gp/ english/, last access: 21 August 2009.

Kato, N., and Akimoto, H.: Anthropogenic emissions of $\mathrm{SO}_{2}$ and $\mathrm{NO}_{\mathrm{x}}$ in Asia: Emission inventories, Atmos. Environ., 26A, 2997-3017, 1992.

Kim, S. W., Heckel, A., McKeen, S. A., Frost, G. J., Hsie, E. Y., Trainer, M. K., Richter, A., Burrows, J. P., Peckham, S. E., and Grell, G. A.: Satellite-observed US power plant $\mathrm{NO}_{\mathrm{x}}$ emission reductions and their impact on air quality, Geophys. Res. Lett., 33, L22812, doi:10.1029/2006GL027749, 2006.

Kim, S.-W., Heckel, A., Frost, G. J., Richter, A., Gleason, J., Burrows, J. P., McKeen, S., Hsie, E.-Y., Granier, C., and Trainer, M.: $\mathrm{NO}_{2}$ columns in the western United States observed from space and simulated by a regional chemistry model and their implications for $\mathrm{NO}_{\mathrm{x}}$ emissions, J. Geophys. Res., 114, D11301, doi:10.1029/2008JD011343, 2009.

Klaassen, G.: Options and Costs of Controlling Ammonia Emissions in Europe, Agricult. Econom., 21, 219-240, 1994.

Klimont, Z.: Current and Future Emissions of Ammonia in China. 10th International Emission Inventory Conference - "One Atmosphere, One Inventory, Many Challenges", US EPA, http://www. epa.gov/ttn/chief/conference/ei10/ammonia/klimont.pdf, last access: 22 December 2008, 2001a.

Klimont, Z.: Ammonia Emissions, Abatement Technologies and 
Related Costs for Europe in the RAINS model, International Institute for Applied Systems Analysis (IIASA), Laxenburg, Austria, 2001b.

Lee, D. S., Köhler, I., Grobler, E., Rohrer, F., Sausen, R., GallardoKlenner, L., Olivier, J. G. J., Dentener, F. J., and Bouwman, A. F.: Estimations of global $\mathrm{NO}_{\mathrm{x}}$ emissions and their uncertainties, Atmos. Environ., 31, 1735-1749, 1997.

Lehmann, C. M. B., Bowersox, V. C., Larson, R. S., and Larson, S. M.: Monitoring long-term trends in sulphate and ammonium in US precipitation: results from the National Atmospheric Deposition Program/National Trends Network, Water Air Soil Pollut. Focus, 7, 1567-7230, 2007, http://bqs.usgs.gov/acidrain/ Deposition_trends.pdf, last access: 1 August 2007.

Li, Y. E. and Lin, E.: Emissions of $\mathrm{N}_{2} \mathrm{O}, \mathrm{NH}_{3}$ and $\mathrm{NO}_{\mathrm{x}}$ from fuel combustion, industrial processes and the agricultural sectors in China, Nutr. Cycl. Agroecosyst., 57, 99-106, 2000.

Li, C., Zhuang, Y., and Cao, M.: Comparing a national inventory of $\mathrm{N}_{2} \mathrm{O}$ emissions from arable lands in China developed with a process-based agroecosystem model to the IPCC methodology, Nutr. Cycl. Agroecosyst., 60, 159-170, 2001.

Lu, Y. Y., Huang, Y., Zou, J. W., and Zheng, X. H.: An inventory of $\mathrm{N}_{2} \mathrm{O}$ emissions from agriculture in China using precipitationrectified emission factor and background emission, Chemosphere, 65, 1915-1924, 2006.

Ma, J. and Zhou, X. J.: Development of a three dimensional inventory of aircraft $\mathrm{NO}_{\mathrm{x}}$ emissions over China, Atmos. Environ., 34, 389-396, 2000.

Mosier, A. R., Duxbury, J. M., Freney, J. R., Heinemeyer, O., and Minami, K.: Assessing and mitigating $\mathrm{N}_{2} \mathrm{O}$ emissions from agricultural soils, Clim. Change, 40, 7-38, 1998.

NARSTO: Improving Emission Inventories for Effective Air Quality Management across North America, 2005.

Ohara, T., Akimoto, H., Kurokawa, J., Horii, N., Yamaji, K., Yan, X., and Hayasaka, T.: An Asian emission inventory of anthropogenic emission sources for the period 1980-2020, Atmos. Chem. Phys., 7, 4419-4444, 2007, http://www.atmos-chem-phys.net/7/4419/2007/.

Olivier, J. G. J., Bouwman, A. F., Berdowski, J. J. M., Veldt, C., Bloos, J. P. J., Visschedijk, A. J. H., Van der Maas, C. W. M., and Zandveld, P. Y. J.: Sectoral emission inventories of greenhouse gases for 1990 on a per country basis as well as on $1^{\circ} \times 1^{\circ}$, Environ. Sci. Pol., 2, 241-264, 1999.

Olivier, J. G. J. and Berdowski, J. J. M.: Global emissions sources and sinks, in: The Climate System, edited by: Berdowski, J., Guicherit, R., and Heij, B. J., A. A. Balkema Publishers/Swets \& Zeitlinger Publishers, Lisse, The Netherlands, 33-78, 2001.

Olivier, J. G. J., Van Aardenne, J. A., Dentener, F., Ganzeveld, L., and Peters, J. A. H. W.: Recent trends in global greenhouse gas emissions: regional trends and spatial distribution of key sources, in: "Non- $\mathrm{CO}_{2}$ Greenhouse Gases (NCGG-4)", van Amstel, A. (coord.), Millpress, Rotterdam, The Netherlands, ISBN: 90-5966-043-9, 325-330, 2005.

Parrish, D. D.: Critical evaluation of US on-road vehicle emission inventories, Atmos. Environ., 40, 2288-2300, 2006.

Pinder, R. W., Adams, P. J., Pandis, S. N., and Gilliland, A. B.: Temporally Resolved Ammonia Emission Inventories: Current Estimates, Evaluation Tools, and Measurement Needs, J. Geophys. Res., 111, D16310, doi:10.1029/2005JD006603, 2006.

Press, A.: China Agricultural Yearbook (in Chinese), Agricultural
Press, Beijing, China, 1996.

Ravishankara, A. R., Daniel, J. S., Portmann, R. W.: Nitrous Oxide $\left(\mathrm{N}_{2} \mathrm{O}\right)$ : The Dominant Ozone-Depleting Substance Emitted in the $21^{\text {st }}$ Century. Science, 123-125, doi:10.1126/science.1176985, 2009.

Reis, S., Pfeiffer, H., Scholz, Y., and Theloke, J.: Temporal and Spatial Distribution of Carbon Emissions, in: The ContinentalScale Greenhouse Gas Balance of Europe, edited by: Dolman, H., Springer Publishers, 2008

Richter, A., Burrows, J.P., Nüß, H., Granier, C., and Niemeier, U.: Increase in tropospheric nitrogen dioxide levels over China observed from space, Nature, 437, 129-132, 2005

Rypdal, K. and Winiwarter, W.: Uncertainties in Greenhouse Gas Inventories - Evaluation, comparability and implications, Environ. Sci. Pol., 4, 107-116, 2001.

Skiba, U., Sozanska, M., Metcalfe, S., and Fowler, D.: Spatially disaggregated inventories of soil $\mathrm{NO}$ and $\mathrm{N}_{2} \mathrm{O}$ emissions for Great Britain., Water Air Soil Poll., 1, 109-118, 2001.

Streets, D. G. and Waldhoff, S. T.: Present and future emissions of air pollutants in China: $\mathrm{SO}_{2}, \mathrm{NO}_{\mathrm{x}}$ and $\mathrm{CO}$, Atmos. Environ., 34, 363-374, 2000.

Streets, D. G., Bond, T. C., Carmichael, G. R., Fernandes, S. D., Fu, Q., He, D., Klimont, Z., Nelson, S. M., Tsai, N. Y., Wang, M. Q., Woo, J.-H., and Yarber, K. F.: An inventory of gaseous and primary aerosol emissions in Asia in the year 2000, J. Geophys. Res., 108, 8809, doi:10.1029/2002JD003093, 2003.

Sutton, M. A., Dragosits, U., Tang. Y. S., and Fowler, D.: Ammonia emissions from non agricultural sources in the UK, Atmos. Environ., 34(6), 855-869, 2000.

Sutton, M. A., Asman, W. A. H., Ellerman, T., van Jaarsveld, J. A., Acker, K., Aneja, V., Duyzer, J. H., Horvath, L., Paramonov, S., Mitosinkova, M., Tang, Y. S., Achermann, B., Gauger, T., Bartnicki, J., Neftel, A., and Erisman, J. W.: Establishing the link between ammonia emission control and measurements of reduced nitrogen concentrations and deposition, Environ. Monit. Assess., 82, 149-185, 2003.

Sutton, M. A., Nemitz, E., Erisman, J. W., Beier, C., Butterbach Bahl, K., Cellier, P., de Vries, W., Cotrufo, M. F., Skiba, U., et al.: Challenges in quantifying biosphere-atmosphere exchange of nitrogen species, Environ. Poll., 150, 125-139, 2007.

Sutton, M. A., Erisman, J. W., Dentener, F., and Moeller, D.: Ammonia in the environment: from ancient times to the present, Environ. Poll., 156, 583-604, 2008.

Tian, H. Z., Hao, J. M., Lu, Y. Q., and Zhu, T. L.: The $\mathrm{NO}_{\mathrm{x}}$ emission distribution and inventory in China, China Environ. Sci., 21, 493-497, 2001.

UNEP: The Nanjing Declaration on Nitrogen Management Presented to the United Nations Environment Programme, 16th of October 2004, UNEP, Nanjing, China, 2004.

UNFCCC: Greenhouse Gas Inventory Data: http://unfccc.int/ghg data/items/3800.php, last access: 20 August 2009, 2009.

USDA: Agricultural Projections to 2016, USDA 2007.

USEPA: National Emission Inventory Tier Summaries: http:// www.epa.gov/ttn/chief/eiinformation.html, last access 14 August 2009, 2009a

USEPA: Inventory of US Greenhouse Gas Emissions and Sinks: 1990-2007, http://epa.gov/climatechange/emissions/ usinventoryreport.html last access: 14 August 2009, 2009b.

Van Aardenne, J. A., Carmichael, G. R., Levy II, H., Streets, D., 
and Hordjik, L.: Anthropogenic $\mathrm{NO}_{\mathrm{x}}$ emissions in Asia in the period 1990-2020, Atmos. Environ., 33, 633-646, 1999.

Van Aardenne, J. A., Dentener, F. J., Olivier, J. G. J., Klein Goldewijk, C. G. M. and Lelieveld, J.: A $1 \times 1$ degree resolution dataset of historical anthropogenic trace gas emissions for the period 1890-1990, Global Biogeochem. Cy., 15(4), 909-928, 2001.

Van Aardenne, J. A., Dentener, F., Olivier, J. G. J., and Peters, J. A. H. W.: The EDGAR 3.2 Fast Track 2000 dataset (32FT2000), 2005.

van der A, R. J., Peters, D. H. M. U., Eskes, H., Boersma, K. F., Van Roozendael, M., De Smedt, I., and Kelder, H. M.: Detection of the trend and seasonal variation in tropospheric $\mathrm{NO}_{2}$ over China, J. Geophys. Res., 111, D12317, doi:10.1029/2005JD006594, 2006.

Velthof, G. L., Oudendag, D., Witzke, H. P., Asman, W. A. H., Klimont, Z., and Oenema, O.: Integrated assessment of nitrogen emissions from agriculture in EU-27 using MITERRA EUROPE, J. Environ. Qual., 38, 402-417, doi:10.2134/jeq2008.0108, 2009.

Vestreng, V., Ntziachristos, L., Semb, A., Reis, S., Isaksen, I. S. A., and Tarrasón, L.: Evolution of $\mathrm{NO}_{\mathrm{x}}$ emissions in Europe with focus on road transport control measures, Atmos. Chem. Phys. Discuss., 8, 10697-10747, 2008,

http://www.atmos-chem-phys-discuss.net/8/10697/2008/.
Wallace, J. M. and Hobbes, P. V.: Atmospheric Science - An Introductory Survey. 2nd Edition, Elsevier Publishers, 2006.

Winiwarter, W. and Rypdal, K.: Assessing the uncertainty associated with national greenhouse gas emission inventories: a case study for Austria, Atmos. Environ., 35, 5425-5440, 2001.

Xing, G. X.: $\mathrm{N}_{2} \mathrm{O}$ emission from cropland in China, Nutr. Cy. Agroecosyst., 52, 249-254, 1998.

Yan, X. Y., Akimoto, H., and Ohara, T.: Estimation of nitrous oxide, nitric oxide and ammonia emissions from croplands in East, Southeast and South Asia, Global Change Biol., 9, 1080-1096, 2003.

Zhao, D. and Wang, A.: Estimation of Anthropogenic Ammonia Emissions in Asia, Atmos. Environ., 28, 689-694, 1994.

Zheng, X. H., Han, S. H., Huang, Y., Wang, Y. S., and Wang, M. X.: Re-quantifying the emission factors based on field measurements and estimating the direct $\mathrm{N}_{2} \mathrm{O}$ emission from Chinese croplands, Global Biogeochem. Cy., 18, GB2018, doi:10.1029/2003GB002167, 2004.

Zhang, Q., Streets, D. G., He, K., Wang, Y., Richter, A., Burrows, J. P., Uno, I., Jang, C. J., Chen, D., Yao, Z., and Lei, Y.: $\mathrm{NO}_{\mathrm{x}}$ emission trends for China, 1995-2004: The view from the ground and the view from space, J. Geophys. Res., 112, D22306, doi:10.1029/2007JD008684, 2007. 